\title{
Mesenchymal Stromal Cell-Based Bone Regeneration Therapies: From Cell Transplantation and Tissue Engineering to Therapeutic Secretomes and Extracellular Vesicles
}

\author{
Darja Marolt Presen ${ }^{1,2 *}$, Andreas Traweger ${ }^{2,3}$, Mario Gimona $^{4}$ and Heinz Redl ${ }^{1,2}$ \\ ${ }^{1}$ Ludwig Boltzmann Institute for Experimental and Clinical Traumatology, AUVA Research Center, Vienna, Austria, ${ }^{2}$ Austrian \\ Cluster for Tissue Regeneration, Vienna, Austria, ${ }^{3}$ Spinal Cord Injury \& Tissue Regeneration Center Salzburg, Institute of \\ Tendon and Bone Regeneration, Paracelsus Medical University, Salzburg, Austria, ${ }^{4}$ GMP Unit, Spinal Cord Injury \& Tissue \\ Regeneration Center Salzburg, Paracelsus Medical University, Salzburg, Austria
}

OPEN ACCESS

Edited by:

Martin James Stoddart AO Research Institute, Switzerland

Reviewed by: Antonio Salgado, University of Minho, Portugal Anna Lange-Consiglio,

University of Milan, Italy

${ }^{*}$ Correspondence: Darja Marolt Presen darja.marolt@trauma.lbg.ac.at

Specialty section:

This article was submitted to Tissue Engineering and Regenerative Medicine,

a section of the journal Frontiers in Bioengineering and Biotechnology

Received: 06 September 2019 Accepted: 06 November 2019 Published: 27 November 2019

Citation:

Marolt Presen D, Traweger A, Gimona M and Redl H (2019)

Mesenchymal Stromal Cell-Based

Bone Regeneration Therapies:

From Cell Transplantation and

Tissue Engineering to Therapeutic Secretomes and Extracellular Vesicles.

Front. Bioeng. Biotechnol. 7:352.

doi: 10.3389/fbioe.2019.00352
Effective regeneration of bone defects often presents significant challenges, particularly in patients with decreased tissue regeneration capacity due to extensive trauma, disease, and/or advanced age. A number of studies have focused on enhancing bone regeneration by applying mesenchymal stromal cells (MSCs) or MSC-based bone tissue engineering strategies. However, translation of these approaches from basic research findings to clinical use has been hampered by the limited understanding of MSC therapeutic actions and complexities, as well as costs related to the manufacturing, regulatory approval, and clinical use of living cells and engineered tissues. More recently, a shift from the view of MSCs directly contributing to tissue regeneration toward appreciating MSCs as "cell factories" that secrete a variety of bioactive molecules and extracellular vesicles with trophic and immunomodulatory activities has steered research into new MSC-based, "cell-free" therapeutic modalities. The current review recapitulates recent developments, challenges, and future perspectives of these various MSC-based bone tissue engineering and regeneration strategies.

\footnotetext{
Keywords: mesenchymal stromal cells, stem cells, MSCs, secretome, extracellular vesicles, cell therapy, bone tissue engineering, bone regeneration
}

\section{INTRODUCTION}

Regeneration of bone defects often presents significant challenges, particularly in patients with decreased tissue regeneration capacity due to extensive tissue damage, disease, advanced age, and confounding systemic and lifestyle factors (Gruber et al., 2006; Borrelli et al., 2012). Between 5 and $10 \%$ of all bone fractures, according to some reports even up to $50 \%$, result in delayed or failed healing (Tzioupis and Giannoudis, 2007; Gómez-Barrena et al., 2015; Ekegren et al., 2018). To overcome these barriers, a number of research studies focused on enhancing bone regeneration by applying mesenchymal stromal cells (MSCs) derived from various connective tissues. Ex vivo processing and culture methods have been developed to obtain sufficient MSC numbers for therapy 
(Schallmoser et al., 2009; Sensebé et al., 2013; Robey et al., 2015). Furthermore, MSCs have been combined with various scaffolds and signaling factors in order to tissue engineer viable "bone substitutes" recapitulating key features of autologous bone grafts and enhancing bone regeneration (Frohlich et al., 2008; Jakob et al., 2012). In vitro culture of these constructs in order to drive cell differentiation, bone-like matrix deposition, and increased mechanical properties has also been extensively studied (Marolt et al., 2006; Grayson et al., 2011; Bhumiratana et al., 2016; Vetsch et al., 2016; Mitra et al., 2017; Zhao et al., 2018). Recapitulation of mechanisms present during embryonic bone development was proposed as a "developmental (re)engineering" strategy for the preparation of intermediate grafts capable of forming fully functional bone (Jukes et al., 2008; Tonnarelli et al., 2014; Bernhard et al., 2017). Viable, large bone-like grafts in clinically relevant dimensions (several millimeters to centimeters in size) have been achieved using dynamic culture of scaffolds seeded with MSCs in bioreactors (Grayson et al., 2010, 2011; Güven et al., 2011; Sørensen et al., 2012; Bhumiratana et al., 2016). In addition, in some cases these grafts comprised rudimentary vascular networks. Bone marrow and adipose tissue MSCs were used in the majority of preclinical and clinical studies (Marolt et al., 2010; Robey, 2011; Grayson et al., 2015; Nancarrow-Lei et al., 2017) (Table 1). However, various other sources of MSCs have also been investigated, including skeletal muscle, bone, cartilage, tendon, dental pulp, perinatal tissues (e.g., Wharton's Jelly, umbilical vein/cord blood, amnion, placenta), embryonic stem cells and induced pluripotent stem cells. Due to the aging-related decline in tissue regeneration (Kassem and Marie, 2011; Marie, 2014; Baker et al., 2015; Bhattacharjee et al., 2019), involving both intra- as well as extra-cellular mechanisms, perinatal tissues and induced pluripotent stem cells have raised interest as potential sources of "young" MSCs with high regenerative properties (Kern et al., 2006; Baksh et al., 2007; Robey, 2011; De Peppo et al., 2013; Ghasemzadeh et al., 2018; Spitzhorn et al., 2019).

Despite this growing knowledge, the translation of MSC-based bone regeneration strategies from research studies to clinical use has been slow (Jakob et al., 2012; Grayson et al., 2015). Limited mechanistic understanding of MSC therapeutic actions and MSC fate following transplantation (Dupont et al., 2010; Manassero et al., 2016) has made the requirements for therapeutic preparations, such as optimal cell numbers, cell phenotype, maturity, and mechanical properties of tissue-engineered grafts difficult to define (Jakob et al., 2012; Oryan et al., 2017). Technical challenges and high costs related to manufacturing under good manufacturing practice (GMP) guidelines and procedures for regulatory approval of MSC therapies (e.g., under advanced therapy medicinal products (ATMP) classification) pose additional barriers for clinical translation (Sensebé et al., 2013). According to our recent search in one of the clinical

\footnotetext{
Abbreviations: ASCs, adipose stromal cells; ATMP, advanced therapy medicinal product; CFU, colony forming units; EV, extracellular vesicle; GMP, good manufacturing practice; hESCs, human embryonic stem cells; hiPSCs, human induced pluripotent stem cells; MNCs, mononuclear cells; MSCs, mesenchymal stromal cells; NO, nitric oxide; SVF, stromal vascular fraction; TE, tissue engineering.
}

trials databases (www.clinicaltrials.gov, July 2019, combinations of search terms "bone regeneration," "bone fracture," "alveolar bone," “maxilla," "osteonecrosis," and "stem cells"), a number of clinical trials (mostly phase I and I/II) employing MSCs to enhance bone regeneration have been registered. However, only for a few the research findings have been published (Table 1).

In recent years, a shift from the view of MSCs as being cells that directly contribute to new tissue formation toward seeing MSCs as "medicinal cell factories" that secrete a variety of bioactive molecules with trophic and immunomodulatory activities has steered the research into MSC secretome for bone regeneration (Hofer and Tuan, 2016; Caplan, 2017). MSCs also secrete various types of extracellular vesicles (EVs) which contain proteins, lipids, and nucleic acids with potential proregenerative properties (Marote et al., 2016; Börger et al., 2017; Turchinovich et al., 2019; van Balkom et al., 2019). Several recent studies in small animal models suggested the therapeutic potential of unfractionated MSC secretome as well as MSCderived extracellular vesicles for bone regeneration (Table 2). In the current review, we recapitulate the recent developments in bone regeneration strategies employing MSC transplantation and MSC-based tissue engineering, as well as the use of MSC secretome and vesicular fractions (Figure 1). Finally, we discuss the challenges and future perspective of these various MSC-based bone regeneration strategies.

\section{SOURCES AND CULTURE OF MSCs FOR BONE REGENERATION THERAPIES}

According to a consensus position statement, the term MSCs is used to describe a population of multipotent mesenchymal stromal cells that: (1) can be isolated based on their ability to adhere and grow on tissue culture plastic surface, (2) exhibit a defined pattern of positive and negative surface markers, and (3) have the ability to undergo differentiation into osteogenic, chondrogenic, and adipogenic lineages under standard in vitro conditions (Dominici et al., 2006). The cells corresponding to this definition were initially isolated from the bone marrow (Friedenstein et al., 1987; Pittenger et al., 1999) and subsequently from many other fetal and adult tissues, including bone, adipose tissue, muscle, blood, dental pulp, placenta, amnion-amniotic fluid, umbilical cord/cord blood etc. (Sudo et al., 2007; Crisan et al., 2008). Importantly, the "stemness" of MSCs, i.e., their ability to self-renew in vivo, has only been shown for some MSC subpopulations from the bone marrow by serial transplantation assays (Sacchetti et al., 2007; Méndez-Ferrer et al., 2010). As a surrogate measure of stem cells present in cell preparations, a colony forming units (CFU) assay was commonly used (Robey, 2011) and this was suggested to correspond to the bone forming capacity in vivo (Braccini et al., 2007). Only recently, the identity of genuine, self-replicating skeletal stem cells has been described (Chan et al., 2018). Nevertheless, the possibility to relatively easily isolate, culture, and differentiate MSCs from various tissues, particularly those remaining as medical waste (e.g., lipoaspirate, perinatal tissues), has fueled the research into MSCs for bone regeneration therapies. 
TABLE 1 | Clinical studies using MSCs and isolated progenitors for bone regeneration.

\begin{tabular}{|c|c|c|c|c|c|c|c|c|}
\hline Identifier & Phase & Completion & Condition & Cell type & Patients & Treatment groups & Masking & $\begin{array}{l}\text { Main outcome } \\
\text { (Reference) }\end{array}$ \\
\hline \multicolumn{9}{|c|}{ SEARCH TERMS: "BONE FRACTURE, STEM CELLS” } \\
\hline NCT02483364 & $\|$ & Recruiting & Pseudoarthrosis & $\begin{array}{l}\text { Autologous or } \\
\text { allogeneic adipose } \\
\text { MSCs }\end{array}$ & Est. 12 & $\begin{array}{l}\text { Allogeneic stem cell } \\
\text { application with } \\
\text { tricalcium phosphate } \\
\text { Autologous stem cell } \\
\text { application with } \\
\text { tricalcium phosphate }\end{array}$ & None & / \\
\hline NCT01842477 & I/II & $\begin{array}{l}\text { February } \\
2016\end{array}$ & $\begin{array}{l}\text { Delayed union } \\
\text { Non-union }\end{array}$ & $\begin{array}{l}\text { Autologous bone } \\
\text { marrow MSCs } \\
\text { (cultured) }\end{array}$ & 30 & $\begin{array}{l}\text { Application of stem } \\
\text { cells with bone } \\
\text { substitute }\end{array}$ & None & $\begin{array}{l}\text { No severe adverse events } \\
\text { and } 26 / 28 \text { treated patients } \\
\text { radiologically healed at } 1 \\
\text { year (Gómez-Barrena et al., } \\
\text { 2019) }\end{array}$ \\
\hline NCT01813188 & $\|$ & $\begin{array}{l}\text { December } \\
2013\end{array}$ & Pseudoarthrosis & $\begin{array}{l}\text { Autologous bone } \\
\text { marrow MNCs }\end{array}$ & 5 & $\begin{array}{l}\text { Application of cells } \\
\text { seeded on tricalcium } \\
\text { phosphate }\end{array}$ & None & / \\
\hline NCT01788059 & $\|$ & $\begin{array}{l}\text { November } \\
2013\end{array}$ & Non-union & $\begin{array}{l}\text { Autologous bone } \\
\text { marrow MSCs (Ficoll } \\
\text { separated) }\end{array}$ & 19 & Stem cell injection & None & / \\
\hline NCT01581892 & $|/| \mid$ & $\begin{array}{l}\text { January } \\
2013\end{array}$ & Non-union & $\begin{array}{l}\text { Autologous bone } \\
\text { marrow MNCs (Ficoll } \\
\text { separated) }\end{array}$ & 7 & Stem cell injection & None & / \\
\hline NCT00916981 & |/II & June 2009 & $\begin{array}{l}\text { Non-union } \\
\text { Pseudoarthrosis }\end{array}$ & $\begin{array}{l}\text { Autologous bone } \\
\text { marrow derived } \\
\text { pre-osteoblastic cells }\end{array}$ & 30 & $\begin{array}{l}\text { Pre-osteoblastic cell } \\
\text { injection }\end{array}$ & None & / \\
\hline NCT02140528 & $\|$ & April 2016 & Tibial fracture & $\begin{array}{l}\text { Allogeneic adipose } \\
\text { MSCs }\end{array}$ & 40 & $\begin{array}{l}\text { Stem cell injection } \\
\text { Control } \\
\text { placebo injection }\end{array}$ & Double & / \\
\hline NCT00512434 & NA & $\begin{array}{l}\text { September } \\
2013\end{array}$ & $\begin{array}{l}\text { Tibial fracture, } \\
\text { open fracture }\end{array}$ & $\begin{array}{l}\text { Autologous bone } \\
\text { marrow MNCs }\end{array}$ & 85 & $\begin{array}{l}\text { Stem cell injection and } \\
\text { osteosynthesis } \\
\text { Control } \\
\text { osteosynthesis only }\end{array}$ & None & / \\
\hline NCT00250302 & $|/| \mid$ & April 2011 & Tibial fracture & $\begin{array}{l}\text { Autologous bone } \\
\text { marrow MSCs } \\
\text { (isolated) }\end{array}$ & 24 & $\begin{array}{l}\text { Stem cell implantation } \\
\text { with autologous platelet } \\
\text { rich } \\
\text { plasma/demineralized } \\
\text { bone carrier } \\
\text { Control no treatment }\end{array}$ & None & $\begin{array}{l}\text { Shorter time to union in } \\
\text { stem cell group ( } 1.5 \\
\text { months) compared to } \\
\text { control group ( } 3 \text { months) } \\
\text { (Liebergall et al., 2013) }\end{array}$ \\
\hline NCT02755922 & III & $\begin{array}{l}\text { December } \\
2010\end{array}$ & $\begin{array}{l}\text { Mandibular } \\
\text { fracture }\end{array}$ & $\begin{array}{l}\text { Autologous adipose } \\
\text { MSCs (24 h } \\
\text { post-isolation) }\end{array}$ & 20 & $\begin{array}{l}\text { Stem cell application } \\
\text { Control no application }\end{array}$ & Single & $\begin{array}{l}\text { Ossification values in stem } \\
\text { cell group were similar to } \\
\text { control at } 4 \text { weeks and } \\
\text { higher as control at } 12 \\
\text { weeks (Castillo-Cardiel } \\
\text { et al., 2017) }\end{array}$ \\
\hline
\end{tabular}


TABLE 1 | Continued

\begin{tabular}{|c|c|c|c|c|c|c|c|c|}
\hline Identifier & Phase & Completion & Condition & Cell type & Patients & Treatment groups & Masking & $\begin{array}{l}\text { Main outcome } \\
\text { (Reference) }\end{array}$ \\
\hline NCT01532076 & III & $\begin{array}{l}\text { September } \\
2014 \\
\text { (terminated) }\end{array}$ & $\begin{array}{l}\text { Osteoporotic } \\
\text { fracture }\end{array}$ & $\begin{array}{l}\text { Autologous stromal } \\
\text { vascular fraction }\end{array}$ & 8 & $\begin{array}{l}\text { Application of } \\
\text { cell-seeded } \\
\text { hydroxyapatite/fibrin } \\
\text { gel graft } \\
\text { Control acellular } \\
\text { composite graft }\end{array}$ & Single & / \\
\hline NCT03766217 & III & $\begin{array}{l}\text { Not yet } \\
\text { recruiting }\end{array}$ & $\begin{array}{l}\text { Cleft lip and } \\
\text { palate }\end{array}$ & $\begin{array}{l}\text { Autologous MSCs from } \\
\text { deciduous dental pulp } \\
\text { (enzyme isolated) }\end{array}$ & Est. 62 & $\begin{array}{l}\text { Application of stem } \\
\text { cells with collagen and } \\
\text { hydroxyapatite } \\
\text { Control autologous } \\
\text { bone graft }\end{array}$ & None & / \\
\hline NCT02751125 & । & $\begin{array}{l}\text { Recruiting } \\
\text { by } \\
\text { invitation }\end{array}$ & Bone atrophy & $\begin{array}{l}\text { Autologous bone } \\
\text { marrow MSCs } \\
\text { (cultured) }\end{array}$ & 13 & $\begin{array}{l}\text { Application of stem } \\
\text { cells mixed with } \\
\text { biphasic calcium } \\
\text { phosphate }\end{array}$ & None & $\begin{array}{l}\text { Treatment resulted in bone } \\
\text { formation sufficient for } \\
\text { dental implant placement } \\
\text { after } 4-6 \text { months (Gjerde } \\
\text { et al., 2018) }\end{array}$ \\
\hline NCT03070275 & $|/| \mid$ & $\begin{array}{l}\text { December } \\
2017\end{array}$ & $\begin{array}{l}\text { Implant } \\
\text { therapy }\end{array}$ & $\begin{array}{l}\text { Autologous alveolar } \\
\text { bone marrow MSCs (in } \\
\text { vitro expanded) }\end{array}$ & 20 & $\begin{array}{l}\text { Application of stem } \\
\text { cells with autologous } \\
\text { fibrin glue in collagen } \\
\text { scaffold }\end{array}$ & Single & / \\
\hline NCT02449005 & $|/| \mid$ & $\begin{array}{l}\text { December } \\
2016\end{array}$ & $\begin{array}{l}\text { Chronic } \\
\text { periodontitis }\end{array}$ & $\begin{array}{l}\text { Autologous alveolar } \\
\text { bone marrow MSCs (in } \\
\text { vitro expanded) }\end{array}$ & 30 & $\begin{array}{l}\text { Application of stem } \\
\text { cells with autologous } \\
\text { fibrin glue in collagen } \\
\text { scaffold } \\
\text { Control fibrin glue with } \\
\text { collagen scaffold alone } \\
\text { Control no } \\
\text { graft materials }\end{array}$ & Quadruple & / \\
\hline NCT01932164 & NA & $\begin{array}{l}\text { December } \\
2015\end{array}$ & $\begin{array}{l}\text { Cleft lip and } \\
\text { palate }\end{array}$ & $\begin{array}{l}\text { Autologous MSCs from } \\
\text { deciduous dental pulp } \\
\text { (isolated, } \\
\text { characterized, frozen) }\end{array}$ & 5 & $\begin{array}{l}\text { Application of stem } \\
\text { cells with collagen and } \\
\text { hydroxyapatite }\end{array}$ & None & $\begin{array}{l}\text { Bone formation closing the } \\
\text { alveolar cleft after } 6 \text { months } \\
\text { in all patients }\end{array}$ \\
\hline \multicolumn{9}{|c|}{ SEARCH TERMS: "OSTEONECROSIS, STEM CELLS" } \\
\hline NCT02448121 & $|/| \mid$ & $\begin{array}{l}\text { Active, not } \\
\text { recruiting }\end{array}$ & $\begin{array}{l}\text { Avascular } \\
\text { necrosis of } \\
\text { bone in sickle } \\
\text { cell disease } \\
\text { patients }\end{array}$ & $\begin{array}{l}\text { Autologous bone } \\
\text { marrow MNCs }\end{array}$ & Est. 100 & Stem cell injection & None & / \\
\hline NCT01605383 & $|/| \mid$ & $\begin{array}{l}\text { Active, not } \\
\text { recruiting }\end{array}$ & $\begin{array}{l}\text { Avascular } \\
\text { necrosis of } \\
\text { the femoral } \\
\text { head }\end{array}$ & $\begin{array}{l}\text { Autologous bone } \\
\text { marrow MSCs } \\
\text { (cultured) }\end{array}$ & Est. 24 & $\begin{array}{l}\text { Application of cells with } \\
\text { allogeneic bone } \\
\text { Control standard } \\
\text { treatment only }\end{array}$ & None & / \\
\hline
\end{tabular}


TABLE 1 | Continued

\begin{tabular}{|c|c|c|c|c|c|c|c|c|}
\hline Identifier & Phase & Completion & Condition & Cell type & Patients & Treatment groups & Masking & $\begin{array}{l}\text { Main outcome } \\
\text { (Reference) }\end{array}$ \\
\hline NCT02065167 & $\|$ & $\begin{array}{l}\text { Active, not } \\
\text { recruiting }\end{array}$ & $\begin{array}{l}\text { Avascular } \\
\text { necrosis of } \\
\text { the femoral } \\
\text { head }\end{array}$ & $\begin{array}{l}\text { Autologous bone } \\
\text { marrow MSCs } \\
\text { (cultured) }\end{array}$ & 26 & Stem cell injection & None & / \\
\hline NCT01700920 & $\|$ & $\begin{array}{l}\text { December } \\
2015\end{array}$ & $\begin{array}{l}\text { Osteonecrosis } \\
\text { of the femoral } \\
\text { head }\end{array}$ & $\begin{array}{l}\text { Autologous bone } \\
\text { marrow MSCs } \\
\text { (cultured) }\end{array}$ & 3 & Stem cell injection & None & / \\
\hline NCT01643655 & NA & $\begin{array}{l}\text { March } \\
2015\end{array}$ & $\begin{array}{l}\text { Avascular } \\
\text { necrosis of } \\
\text { the femoral } \\
\text { head }\end{array}$ & $\begin{array}{l}\text { Autologous adipose } \\
\text { MSCs }\end{array}$ & 15 & Stem cell injection & None & / \\
\hline NCT01198080 & I & June 2013 & $\begin{array}{l}\text { Osteonecrosis } \\
\text { of the femoral } \\
\text { head }\end{array}$ & $\begin{array}{l}\text { Autologous CD133 } \\
\text { bone marrow cells }\end{array}$ & 10 & Stem cell injection & None & $\begin{array}{l}\text { Treatment resulted in } \\
\text { disease score improvement, } \\
\text { reduced joint injuries and } \\
\text { pain relief (Emadedin et al., } \\
\text { 2019) }\end{array}$ \\
\hline NCT00821470 & 1 & $\begin{array}{l}\text { September } \\
2008\end{array}$ & $\begin{array}{l}\text { Osteonecrosis } \\
\text { of the femoral } \\
\text { head }\end{array}$ & $\begin{array}{l}\text { Autologous bone } \\
\text { marrow aspirate }\end{array}$ & 21 & $\begin{array}{l}\text { Bone marrow injection } \\
\text { Control standard } \\
\text { treatment only }\end{array}$ & Triple & / \\
\hline
\end{tabular}

Studies were searched in the Clinicaltrials. gov database (July 2019), using combinations of search terms "bone, bone fracture, stem cells, maxilla, alveolar, osteonecrosis." Registered studies with unknown status and terminated studies were excluded. Cell type designation in the table is according to the information provided for the specific clinical study in the database.

\section{Bone Marrow-Derived MSCs}

Bone marrow has been investigated in most studies as the standard source of MSCs/progenitors contributing to bone repair in vivo (Park et al., 2012; Zhou et al., 2014; Nancarrow-Lei et al., 2017). Bone marrow MSCs have been isolated from individuals of various ages and health backgrounds (Alves et al., 2012; Chadid et al., 2018; Tencerova et al., 2019). Bone marrow MSCs are relatively rare, comprising $<0.01 \%$ of the isolated mononuclear cell (MNC) fraction (Pittenger et al., 1999). Numbers of isolated MSCs vary between individual patients as well as the site and technique used for tissue harvesting (Muschler et al., 1997; Pierini et al., 2013; Patterson et al., 2017; Herrmann et al., 2019). In order to increase MSC numbers for therapeutic use, protocols for in vitro expansion have been developed, employing standardized, animal-supplement-free culture conditions (Schallmoser et al., 2009; Fekete et al., 2012). Bone marrow MSCs can reach over 50 population doublings in vitro (Bianco et al., 2001). However, with increased chronological age of the patient and extended in vitro culture, bone marrow MSC proliferation and differentiation potentials can decline and the proportion of senescent cells can increase, limiting the therapeutic potential (Stolzing et al., 2008; Churchman et al., 2017; Ganguly et al., 2017).

\section{Adipose Tissue-Derived MSCs}

With the discovery of MSC-like cells in adipose tissue lipoaspirates (Zuk et al., 2001), many studies have turned to this waste tissue as a source for MSC isolation. Volumes of lipoaspirate remaining at plastic surgeries can range from milliliters to several liters and reportedly contain a relatively high proportion of MSCs (between 1 and 5\% of the isolated nucleated cells) depending on the donor, harvesting procedure, and tissue harvesting site (Gimble et al., 2007; Jurgens et al., 2008; Dubey et al., 2018). Importantly, some properties of the stromal vascular fraction (SVF) cells isolated from adipose tissue change upon culture in vitro (e.g., expression of surface markers) (Gimble et al., 2007), and the cultured cells are subsequently termed adipose MSCs or adipose tissue stromal cells (ASCs) (Bourin et al., 2013). Adipose MSCs exhibit robust osteogenic differentiation potential in vitro using standard osteogenic supplements (dexamethasone, betaglycerophosphate, and ascorbic acid) (Fröhlich et al., 2010; Brennan et al., 2017). However, in vivo studies using an ectopic transplantation model in nude mice demonstrated important functional differences between bone marrow and adipose MSCs. When culture-expanded (unprimed) MSCs were transplanted together with osteoinductive calcium phosphate biomaterial or with Matrigel, higher bone ossicle formation and the presence of bone marrow compartment were exclusively found with the bone marrow MSCs as compared to adipose MSCs and cells from other sources (Reinisch et al., 2015; Brennan et al., 2017). This limitation might be overcome by in vitro preinduction of adipose MSCs via the endochondral ossification route (Osinga et al., 2016). On the other hand, adipose MSCs contain vasculogenic subpopulations, which might be an advantage for bone healing by promoting neovascularization (Hutton et al., 2014; Brennan et al., 2017). According to recent 
TABLE 2 | Preclinical studies reporting the use of MSC-secretome and MSC-EVs for bone regeneration.

\begin{tabular}{|c|c|c|c|}
\hline References & Cell source & In vivo model & Main outcome of secretome treatment \\
\hline \multicolumn{4}{|c|}{ UNFRACTIONATED SECRETOME/CONDITIONED MEDIUM } \\
\hline Osugi et al. (2012) & Human bone marrow MSCs & Rat calvarial bone defect & $\begin{array}{l}\text { Enhanced bone formation (after } 4 \text { and } 8 \text { weeks), rat MSC } \\
\text { migration into the defect }\end{array}$ \\
\hline Katagiri et al. (2013) & Human bone marrow MSCs & Rat calvarial bone defect & Early bone regeneration (after 2 and 4 weeks) \\
\hline Katagiri et al. (2017) & Human bone marrow MSCs & Rat calvarial bone defect & $\begin{array}{l}\text { Vascular endothelial growth factor is crucial for angiogenesis and } \\
\text { bone regeneration }\end{array}$ \\
\hline Ando et al. (2014) & $\begin{array}{l}\text { Human bone marrow MSCs } \\
\text { Human skin fibroblasts }\end{array}$ & $\begin{array}{l}\text { Mouse distraction } \\
\text { osteogenesis model }\end{array}$ & $\begin{array}{l}\text { Accelerated distraction osteogenesis through endogenous cell } \\
\text { recruitment of MSC secretome } \\
\text { Activity of MSC secretome similar to MSCs transplantation }\end{array}$ \\
\hline Kawai et al. (2015) & Human bone marrow MSCs & Rat periodontal defect & $\begin{array}{l}\text { Periodontal tissue regeneration (after } 4 \text { weeks) and increased } \\
\text { presence of CD31, CD105, and Flk1 positive cells }\end{array}$ \\
\hline Ogata et al. (2015) & Human bone marrow MSCs & $\begin{array}{l}\text { Rat bisphosphonate-related } \\
\text { osteonecrosis of the jaw } \\
\text { model }\end{array}$ & $\begin{array}{l}\text { Increased bone healing with complete soft tissue coverage; } \\
\text { histology demonstrated new bone formation and the presence of } \\
\text { osteoclasts }\end{array}$ \\
\hline Ogata et al. (2018) & $\begin{array}{l}\text { Human bone marrow MSCs } \\
\text { Three cytokines mixture }\end{array}$ & $\begin{array}{l}\text { Rat medication-related } \\
\text { osteonecrosis of the jaw } \\
\text { model }\end{array}$ & $\begin{array}{l}\text { Increased bone healing with soft tissue coverage in conditioned } \\
\text { medium and three cytokines mixture groups }\end{array}$ \\
\hline Fujio et al. (2017) & $\begin{array}{l}\text { Hypoxic human dental pulp } \\
\text { cells }\end{array}$ & $\begin{array}{l}\text { Mouse distraction } \\
\text { osteogenesis model }\end{array}$ & $\begin{array}{l}\text { Increased blood vessel density and higher bone formation (after } 4 \\
\text { weeks) }\end{array}$ \\
\hline Xu et al. (2016) & $\begin{array}{l}\text { Human fetal bone marrow } \\
\text { MSCs }\end{array}$ & $\begin{array}{l}\text { Rat distraction osteogenesis } \\
\text { model }\end{array}$ & $\begin{array}{l}\text { Continuous secretome injection improved bone consolidation } \\
\text { compared to controls }\end{array}$ \\
\hline Wang et al. (2016) & Human fetal MSCs & $\begin{array}{l}\text { Mouse ectopic bone } \\
\text { formation model }\end{array}$ & Restored osteogenic capacity of senescent adult human MSCs \\
\hline \multicolumn{4}{|c|}{ EXTRACELLULAR VESICLES SECRETOME FRACTION } \\
\hline Furuta et al. (2016) & Human bone marrow MSCs & $\begin{array}{l}\text { CD9 negative mouse } \\
\text { fracture healing model }\end{array}$ & EV injections in the fracture site accelerated fracture healing \\
\hline Qin et al. (2016) & Human bone marrow MSCs & Rat calvarial bone defect & EV hydrogel application promoted bone regeneration after 8 weeks \\
\hline Zhang et al. (2016b) & Human ESC-MSCs & $\begin{array}{l}\text { Rat osteochondral defect } \\
\text { model }\end{array}$ & Restoration of cartilage and subchondral bone after 12 weeks \\
\hline Qi et al. (2016) & Human iPSC-MSCs & $\begin{array}{l}\text { Ovariectomized rat calvarial } \\
\text { bone defect }\end{array}$ & EV application stimulated bone regeneration and angiogenesis \\
\hline Li et al. (2018) & Human adipose MSCs & Mouse calvarial bone defect & Enhanced bone regeneration after 6 weeks \\
\hline Zhang et al. (2019) & Human umbilical cord MSCs & $\begin{array}{l}\text { Rat stabilized femoral } \\
\text { fracture model }\end{array}$ & Enhanced angiogenesis and bone healing after 14 and 31 days \\
\hline
\end{tabular}

reports, regenerative properties of adipose MSCs might not be adversely influenced by age, as is often the case with bone marrow MSCs (Dufrane, 2017; Reumann et al., 2018).

\section{MSCs Derived From Perinatal Tissues}

In addition to bone marrow and adipose tissue, perinatal tissues including umbilical cord, cord blood, amniotic membrane, and placenta are of high interest for bone regenerative therapies, particularly as their collection does not require invasive harvesting procedures (Brown et al., 2019). While autologous use of MSCs from these sources might require cell banking for extended periods, the advantage may be in their younger "chronological" age and thus presumably higher regenerative potential compared to the MSCs from adult/elderly patients. Indeed, umbilical cord MSCs reportedly exhibited a higher proliferation capacity, similar or higher osteogenic differentiation, and absence of adipogenic differentiation as compared to bone marrow and adipose-derived MSCs (Kern et al., 2006; Zhang et al., 2011). Similarly, comparative studies indicated that amnion MSCs have higher proliferation rates and comparable or higher osteogenic differentiation compared to bone marrow and adipose MSCs (Topoluk et al., 2017; Ghasemzadeh et al., 2018), and umbilical cord MSCs exhibited higher proliferation and more rapid osteogenic differentiation compared to bone marrow MSCs (Baksh et al., 2007).

\section{Induced Pluripotent Stem Cells-Derived MSCs}

Populations similar to MSCs have been reported in many other adult and fetal tissues, and evidence of their perivascular location points to their role in responses to injury (Caplan, 2008; Crisan et al., 2008). However, practical aspects, such as quantity of tissue available for harvesting, donor site injury, and limited scientific knowledge might preclude their clinical use. In contrast, practically unlimited numbers of autologous MSC-like cells can be obtained by differentiation of human induced pluripotent stem cells (hiPSCs). hiPSCs are derived from the patient's adult somatic cells by nuclear reprogramming using cocktails of transcription factors (and small molecules) with key roles in 


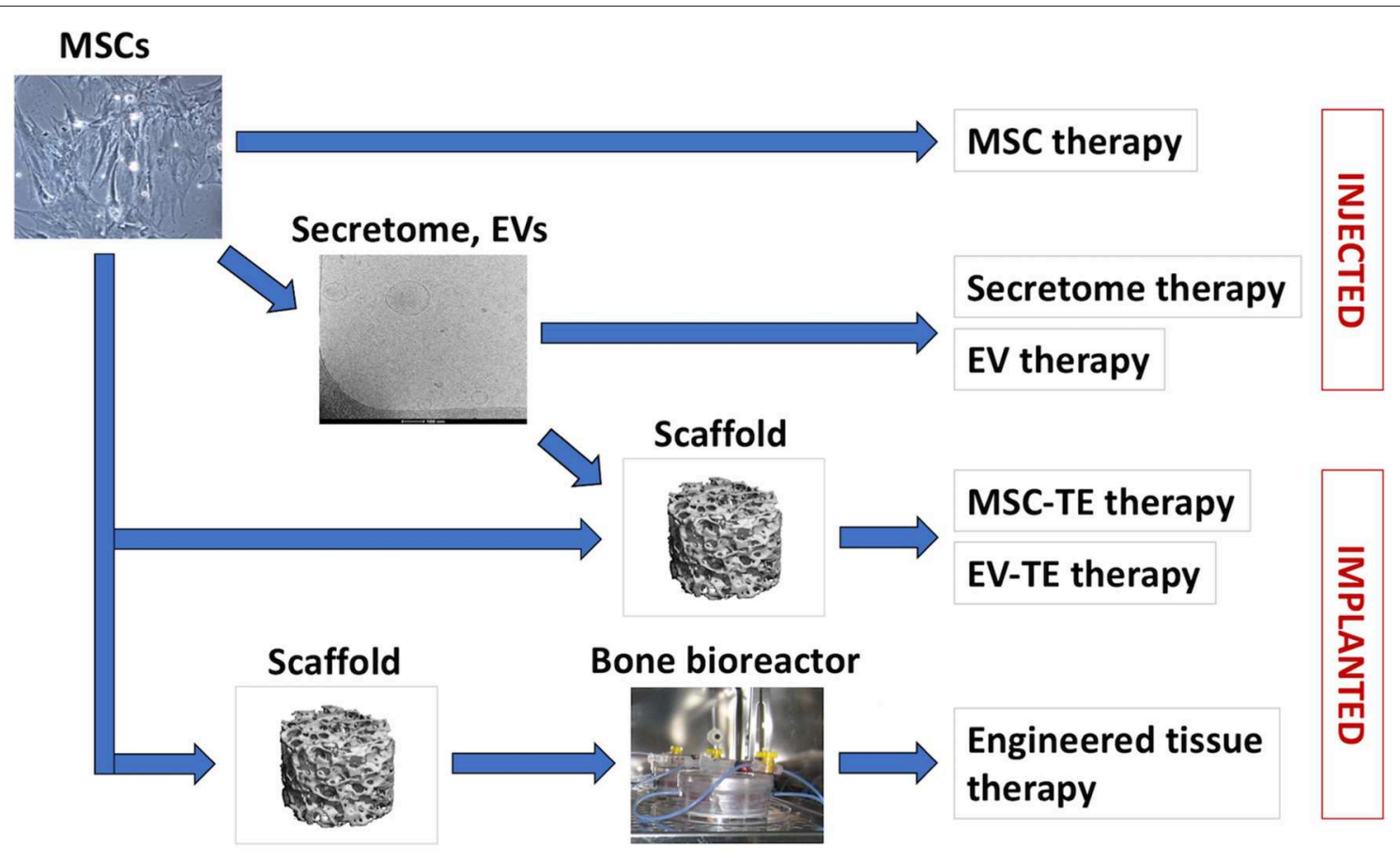

FIGURE 1 | MSC-based bone regeneration strategies. Cultured MSCs can be used for cell therapies or for therapeutic secretome/EVs production (arrow). In tissue engineering (TE) therapies, MSCs or MSC-EVs are applied in combination with biomaterial scaffolds. For certain indications, MSCs are seeded on biomaterial scaffolds and cultured in vitro in bioreactors, to support engineered tissue development and maturation prior to application.

the pluripotency regulation network (Takahashi et al., 2007; Zhu et al., 2010; Ma et al., 2013). hiPSCs largely resemble human embryonic stem cells (hESCs) in their pluripotency (i.e., ability to form differentiated tissues of all three germ layers, confirmed in vivo by teratoma assay) and differentiation potential (Bock et al., 2011; Bilic and Izpisua Belmonte, 2012). A number of studies reported the differentiation of hiPSCs into MSC-like progenitors (hiPSC-MSCs) and further into bone-like tissue in vitro and in vivo (reviewed in De Peppo and Marolt, 2013; Luzzani and Miriuka, 2017; Wu et al., 2017). hiPSC-MSCs largely resemble adult MSCs in surface antigen expression pattern, differentiation potential, and global gene expression and thus correspond to the definition of adult MSCs, though variations are observed between individual lines, similarly to adult MSCs (De Peppo et al., 2013). The procedure of their derivation via nuclear reprogramming of adult/aged somatic cells might be used to "rejuvenate" the regenerative potential of cells from elderly patients (Lapasset et al., 2011; Frobel et al., 2014; Spitzhorn et al., 2019). Further investigations into the hiPSC-MSCs phenotype, stability, safety, and in vivo development in preclinical models are needed (Jung et al., 2012; Levi et al., 2012; De Peppo et al., 2013; Phillips et al., 2014) prior to their consideration for potential clinical use. Nevertheless, hiPSCs offer a unique opportunity for engineering bone organoids containing various cell lineages from a single unlimited cell source, with broad applications in basic studies and translational applications.

\section{Heterogeneity and Changes in MSC Properties During in vitro Culture}

Notably, freshly isolated progenitors as well as cultured MSC populations are highly heterogeneous. Investigations are thus focused on defining the subpopulations endowed with the highest bone regenerative potential that can be procured with minimal manipulation (Caralla et al., 2013; Chung et al., 2015), as well as the development of fast screening methods to predict cell functionality (Li et al., 2016; Murgia et al., 2016). During in vitro culture, MSCs progressively lose their proliferation and differentiation potentials and the proportion of senescent cells increases (Stolzing et al., 2008; Churchman et al., 2017). This functional decline can be mitigated to some extent by the adjustment of culture conditions, including specific media supplements (e.g., the widely used basic fibroblast growth factor) (Martin et al., 1997; Chase et al., 2010) and culture on substrates containing extracellular matrix proteins (Mauney et al., 2004, 2006; Chase et al., 2010; Rakian et al., 2015). Such adaptations might not only preserve MSC biological properties, but also allow efficient MSC expansion for cell banking, repeated therapeutic applications, and the preparation of therapeutic secretome.

Taken together, MSCs isolated from different sources exhibit important differences in their availability, characteristics and regenerative potential. Therefore, the choice of cell source and subsequent isolation and manipulation techniques will depend on the requirements of specific research/clinical applications. 


\section{MSCs-BASED THERAPIES AND BONE TISSUE ENGINEERING \\ MSCs in Clinical Applications}

Cell therapy approaches to regenerate bone were initially based on the premise that the transplanted MSCs would differentiate and form new bone tissue, thus substituting for the activity of endogenous cells compromised by the injury (Bruder and Fox, 1999; Stegemann et al., 2014; Marcucio et al., 2015). Based on the positive outcomes of preclinical studies (Bruder et al., 1998; Petite et al., 2000; Arinzeh et al., 2003; GraneroMoltó et al., 2009; Caralla et al., 2013; Chung et al., 2015), freshly isolated bone marrow mononuclear cells (MNCs) as well as culture-expanded MSCs from bone marrow, adipose tissue, and dental pulp were evaluated clinically in order to enhance the healing of bone fractures, non-unions, various jaw bone defects, and to prevent bone degradation in femoral head osteonecrosis (Table 1) (Stegemann et al., 2014). For fracture non-unions, fluoroscopy-controlled percutaneous injection of autologous MNCs, concentrated from bone marrow aspirates by centrifugation, i.e., the "Hernigou procedure," was reported (Hernigou et al., 2005). Successful bone union was obtained in 53 of 60 patients in whom a significantly higher concentration as well as total number of progenitor cells (evaluated by the CFU assay) were transplanted when compared to the 7 patients who did not achieve a bony union. A positive correlation was found between the total number and the concentration of transplanted CFUs and the volume of mineralized callus at 4 months, and a negative correlation was found between the time needed to obtain union and the concentration of CFUs in the graft (Hernigou et al., 2005). Similarly, Le Nail et al. analyzed a series of 43 patients with open tibial fractures with a risk of developing non-unions or presenting non-unions, some of whom received injections of concentrated bone marrow progenitors. They determined a threshold number of transplanted progenitors above which healing was 100\% successful (Le Nail et al., 2014).

Quarto et al. first reported the application of culture-expanded bone marrow MSCs together with hydroxyapatite biomaterial for the treatment of large bone defects resulting from traumatic fractures and unsuccessful lengthening in three patients (Quarto et al., 2001). Abundant callus formation along the implants and good integration at the interfaces with the host bones 2 months after surgery were reported. There were no adverse reactions to the implants and all three patients recovered full limb function (Quarto et al., 2001). Several other registered clinical studies used autologous bone marrow MNCs, MSCs, or preosteoblasts, either injected or co-applied with bone substitute materials as carriers to treat delayed unions and non-unions of long bones (Table 1). Of these, Emadedin et al. reported that injections of cultured MSCs were safe and evidence of bone union was found in 3 of 5 treated patients (Emadedin et al., 2017). Furthermore, Gomez-Barrena et al. reported that surgical delivery of culture expanded bone marrow MSCs combined with bioceramic granules for the treatment of delayed unions and nonunions was safe and feasible, with 26 of 28 patients exhibiting radiologic healing 1 year after treatment (Gómez-Barrena et al., 2019). For the treatment of tibial, osteoporotic, and mandibular fractures, autologous bone marrow MNCs or MSCs, autologous adipose SVF and autologous or allogeneic adipose MSCs, injected or applied with biomaterials, were studied in comparison to non-cell-therapy controls (Table 1). Liebergall et al. reported that a prophylactic, minimally invasive intervention, involving injection of magnetically-separated bone marrow MSCs, mixed with platelet-rich plasma and demineralized bone matrix (study group, 12 patients), resulted in shorter time to union compared to control group with conventional fracture treatment (12 patients) (Liebergall et al., 2013). Castillo-Cardiel et al. similarly reported that the treatment of mandibular fractures with autologous adipose MSCs (12 patients) resulted in higher ossification rates at 12 weeks compared to the non-cell-therapy control group (12 patients) (Castillo-Cardiel et al., 2017).

Various jaw bone defects were also treated using MSCtherapies, with cells isolated and culture-expanded either from the jaw bone marrow, buccal fat pad, and dental pulp, and subsequently applied in combination with biomaterials (Table 1). Khojasteh et al. reported the treatment of human alveolar cleft defects with buccal fat pad-derived MSCs in combinations with biomaterials. The cell-therapy groups exhibited a trend of higher bone formation after 6 months (Khojasteh et al., 2017). Redondo et al. tested alveolar bone marrow MSCs, osteogenically predifferentiated within an autologous serum-derived scaffolds in vitro, for the treatment of maxillary cysts in 9 patients. They found no adverse effects and an increased density of the cyst interior by computed tomography evaluation (Redondo et al., 2018). Gjerde et al. applied bone marrow MSCs with biphasic calcium phosphate for the treatment of severely atrophied mandibular bone in 13 patients and found no adverse events and sufficient bone regeneration for implant placement after 4-6 months (Gjerde et al., 2018).

Therapies involving autologous bone marrow MNCs or MSCs and adipose MSCs were also evaluated in several studies to treat osteonecrosis of the femoral head (Table 1) (Hernigou and Beaujean, 2002; Hernigou et al., 2018). Hernigou et al. reported that supplementation of the core decompensation procedure with concentrated bone marrow MNCs injections was effective in treating patients with earlier stages of the disease (resulting in less hip replacements), with better outcomes in patients who had greater numbers of progenitors transplanted (Hernigou and Beaujean, 2002). After 20-30 years follow-up, it was reported that core decompression with bone marrow cell injection improved the outcome of the disease (with less hip replacements) as compared with core decompression alone in the same patient group (Hernigou et al., 2018). Recently, injections of magnetically-separated CD133 positive bone marrow progenitors in 9 patients with femoral head osteonecrosis resulted in improved disease scores, less joint injuries, and provided clinically-relevant pain relief (Emadedin et al., 2019). In contrast, Hauzeur et al. reported that implantation of concentrated bone marrow MNCs after core decompression did not produce any improvement in the progression of stage 3 non-traumatic osteonecrosis of the femoral head (Hauzeur et al., 2018).

Taken together, published results of these various clinical studies and reports suggest the overall safety of MSC-based therapeutic approaches, as well as potential enhancement of bone healing compared to control groups. However, differences in 
clinical indications, study designs and the absence of control groups preclude further mechanistic conclusions. Thus far, no MSC-based therapeutic product has become the standard of care for bone regeneration.

Systemic MSC delivery approaches were also investigated, e.g., for the treatment of osteoporosis (Phetfong et al., 2016), as well as novel therapeutic molecules that would enhance the mobility of endogenous MSCs toward the injured bone sites. In this regard, a biphasic small molecule that recruits osteogenic cells to the bone surfaces was reported to improve bone regeneration in a small animal fracture model (Guan et al., 2012; Yao et al., 2016). It was also reported that co-administration of PTH stimulated systemically administered MSCs to migrate to and regenerate spine injuries and vertebral fractures in preclinical models (Sheyn et al., 2016; Cohn Yakubovich et al., 2017). However, these advances have yet to be implemented and tested in the course of controlled clinical studies to Demonstrate enhanced bone regeneration.

\section{Bone Tissue Engineering}

More "advanced" bone tissue engineering approaches are predominantly in the preclinical research phase. These include various combinations of osteogenic cells, biomaterial scaffolds, signaling factors, and graft culture/maturation procedures (in vitro and in vivo) toward "functional" bone substitutes. Initially, most in vitro studies reported smaller bone constructs (up to several millimeters in size and $<0.5 \mathrm{~mm}$ thick), since static culture limits new tissue development due to mass transport by diffusion only, as well as batch feeding regimes. Nevertheless, these smaller constructs allowed the evaluation of differences between various bone biomaterials, growth factor delivery regimes, cell differentiation pathways, and cell types to support new bone matrix deposition and mineralization (Meinel et al., 2006; Correia et al., 2012; Marcos-Campos et al., 2012; Chuenjitkuntaworn et al., 2016; Osinga et al., 2016; Rindone et al., 2019). In order to scale-up and standardize these bone tissue engineering strategies to sizes relevant for preclinical studies in large animal models and for clinical applications (beyond reconstruction of smaller jaw bone defects), research has focused on advanced scaffold manufacturing technologies (recently reviewed in Forrestal et al., 2017) and on dynamic tissue culture in bioreactor systems (Meinel et al., 2004, 2005; Marolt et al., 2006; Timmins et al., 2007; Grayson et al., 2008, 2011; Fröhlich et al., 2010; Woloszyk et al., 2014). Perfusion systems that support the interstitial flow of culture medium through bone scaffolds showed the most promise for bone tissue engineering from MSCs originating from adult tissues and pluripotent stem cells (De Peppo et al., 2013; Vetsch et al., 2016; Mitra et al., 2017; Sladkova et al., 2018). The appropriate biochemical milieu and biophysical stimulation provided to the osteogenic cells by the fluid shear force on the cells allowed increased cell numbers and enhanced the uniform cell distribution and the amount of new bone matrix (Sikavitsas et al., 2003; Grayson et al., 2011; Zhao et al., 2018). Grayson and colleagues were the first to report the bioreactor-based engineering of clinically sized, viable human, bone marrow MSCs-derived bone grafts, precisely fitting the complex anatomy of the temporomandibular joint condylar bone (Grayson et al., 2010). In following studies, several centimeter large ramus condyle grafts containing immature bone tissue were engineered from porcine adipose MSCs and evaluated in vivo in Yucatan minipigs (Bhumiratana et al., 2016). Six months after implantation, the engineered grafts maintained their anatomical structure, integrated with native tissues and generated greater volume of new bone and greater vascular infiltration than either non-seeded anatomical scaffolds or untreated defects (Bhumiratana et al., 2016). These advances are currently under way to be evaluated in a clinical phase-1 study. Sorensen et al. evaluated the effect of bone marrow MNCs precultured on poly-lactic acid-coated bicalcium phosphate scaffolds in perfusion bioreactors on a spine fusion model in sheep (Sørensen et al., 2012). They found that bioreactor-generated, cell-based bone substitutes were as effective as autologous bone grafts and superior to cell-free bone substitutes in their bone fusion ability. However, bone structure was superior in autografts (Sørensen et al., 2012). In a following study, the bioreactor system was automated for the streamlined production of engineered osteogenic grafts (Ding et al., 2016).

Preclinical studies indicated that the survival of cells in engineered bone grafts can be severely limited after in vivo implantation (Giannoni et al., 2010; Becquart et al., 2012; Kaempfen et al., 2015; Manassero et al., 2016). As with autologous grafts, the transplanted tissue that is not immediately connected to the host vasculature is subject to oxygen deprivation and nutrient limitation and the interior portions of the graft undergo necrosis. Pre-vascularization strategies of the tissueengineered bone grafts are thus an intense area of investigation (Barabaschi et al., 2015). For instance, Güven et al. reported that a 5-days perfusion bioreactor culture of adipose SVF within hydroxyapatite scaffolds resulted in capillary network formation, which anastomosed with the host vasculature already 1 week after ectopic nude rat implantation and promoted a faster tissue ingrowth and more abundant and uniform new bone tissue after 8 weeks, as compared to bone marrow or adipose MSC cultures (Güven et al., 2011). MSCs from different sources might also exhibit different sensitivity to hypoxic conditions. For instance, we previously found that hiPSC-derived MSC engineered bone constructs $(\sim 0.5 \mathrm{~cm}$ in size $)$ remained viable for 12 weeks in a subcutaneous site, continued to develop, and functional blood vessels were found within the interior portions of the transplants (De Peppo et al., 2013). Furthermore, the application of tissue engineering protocols involving the endochondral differentiation pathway, which is predominant in the healing of long bones, might allow enhanced survival, vascularization, and remodeling of the transplanted hypertrophic cartilage grafts toward new bone regeneration (Bernhard et al., 2017; Epple et al., 2019).

\section{MSC-DERIVED SECRETOME FOR BONE REGENERATION}

The native process of bone healing proceeds through overlapping stages of inflammation, repair, and remodeling, which involve multiple signaling pathways acting in concert within the bone 
defect and the surrounding soft tissues (Oryan et al., 2017). In vivo studies examining effects of transplanted MSCs on bone regeneration found limited numbers of transplanted cells surviving and engrafting in the defect sites, and the exact mechanisms of the contribution of exogenous MSCs to new tissue formation are not clear (Geuze et al., 2010; Bhumiratana et al., 2016; Manassero et al., 2016; Oryan et al., 2017). In vitro and in vivo studies suggested that the transplanted MSCs can have multiple paracrine effects on endogenous cell populations, including immune cell modulation, angiogenic activity, MSC and endothelial progenitor recruitment, cell proliferation, stem cell differentiation, anti-apoptotic effects, and wound healing (Ponte et al., 2007; Chen et al., 2008; Ando et al., 2014; Hofer and Tuan, 2016; Oryan et al., 2017). Depending on their source and manipulation (Oskowitz et al., 2011), MSCs produce a variety of signaling factors, including: purines, bone morphogenetic proteins, CCL2, Connexin 43, cyclooxygenase/prostaglandin, CD95/CD95 ligand, galectins, heme oxygenase-1, human leukocyte antigen- $G$, interleukin3 , interleukin-6, leukemia inhibitory factor, NO, transforming growth factor beta, vascular endothelial growth factor, hepatocyte growth factor, platelet derived growth factor, basic fibroblast growth factor, and others (Ponte et al., 2007; Chen et al., 2008; Ando et al., 2014; Hofer and Tuan, 2016). The growing understanding of MSC immunomodulatory and trophic activities has steered the research toward the potential of therapeutic MSC secretome, prepared by media conditioning on cultured MSCs, to enhance various stages of bone regeneration (Caplan and Dennis, 2006). In a sense, the use of therapeutic secretome mimics more closely the process of native bone healing by involving multiple signaling factors that work in synergy at low concentrations, rather than a single or a few signaling factors in super-physiologic concentrations (potentially leading to serious side effects, as reported for the high, clinically applied doses of recombinant bone morphogenetic protein therapies) (James et al., 2016). In addition, secretome-based cell-free therapeutic approaches present several significant advantages over current cell- and tissue-based therapies. The absence of replicating (allogeneic) cells in secretome fractions significantly improves the patient safety profile, the low metabolic activity allows for improved quality control and quality assurance, and the simplicity of storage provides the basis for cost-efficient shipping of this potentially off-the-shelf therapeutic substance.

A number of studies evaluated the potential of MSC secretome, either as unfractionated conditioned medium or the extracellular vesicles-enriched fraction, for bone regeneration (Table 2). Secretomes from human adult bone marrow MSCs (Osugi et al., 2012; Katagiri et al., 2013; Ando et al., 2014; Ogata et al., 2015), human dental pulp cells (Fujio et al., 2017), and human fetal MSCs (Wang et al., 2016; Xu et al., 2016) have been investigated. Human adult bone marrow MSC-conditioned media contained insulin-like growth factor-1, vascular endothelial growth factor, hepatocyte growth factor, transforming growth factor beta, monocyte chemoattractant proteins-1 and-3, interleukin-3, and interleukin 6, as determined by ELISA assays (Osugi et al., 2012; Katagiri et al., 2013; Ando et al., 2014; Kawai et al., 2015). Extended analysis of the bone marrow MSC-conditioned medium using a cytokine antibody array yielded 43 proteins with levels at least 1.5-times higher compared to a control medium background (Ando et al., 2014). In particular, serum-free conditioning of the bone marrow MSCs, as reported by most studies (Table 2), was shown to result in a highly angiogenic secretome (Oskowitz et al., 2011).

Osugi et al. reported the potential of human bone marrow MSC-conditioned medium to enhance bone healing in a rat calvarial defect model (Osugi et al., 2012). In vitro, this study demonstrated that conditioned medium from human bone marrow MSCs enhanced the migration, proliferation, and expression of osteogenic marker genes, such as osteocalcin and RUNX2, in rat bone marrow MSCs (Osugi et al., 2012). Application of the conditioned medium with agarose gel in calvarial defects resulted in higher bone regeneration compared to the agarose gel mixed with human bone marrow MSCs or vehicle controls (phosphate buffered saline or culture medium) after 4 and 8 weeks, presumably by enhancing rat MSC migration into the defect (Osugi et al., 2012). A related study by Katagiri et al. confirmed the in vitro findings of Osugi et al. and found that the conditioned medium soaked onto collagen sponges significantly increased early bone regeneration in calvarial defects (after 2 and 4 weeks) compared to the control group (Katagiri et al., 2013). A later study of angiogenesis in the newly regenerated bone suggested vascular endothelial growth factor to be the crucial component in the conditioned medium, promoting angiogenesis and migration of endogenous stem cells (Katagiri et al., 2017). Together, these studies suggested that bone marrow MSC-conditioned medium promotes angiogenesis and bone regeneration in a rat calvarial defect model, but also has the potential to mobilize endogenous MSCs.

Ando et al. demonstrated that repeated applications of human bone marrow MSC-conditioned medium accelerated callus formation in a high-speed mouse distraction osteogenesis model through multiple regenerative mechanisms, similar to the transplantation of bone marrow MSCs (Ando et al., 2014). Analysis of conditioned medium identified factors that recruit mouse bone MSCs, endothelial cells, and endothelial progenitors, inhibit inflammation and apoptosis, and promote osteoblast differentiation, angiogenesis, and cell proliferation. In particular, conditioned medium depleted of monocyte chemoattractant proteins- 1 and -3 failed to recruit mouse bone marrow MSCs and callus formation (Ando et al., 2014). Further studies with human bone marrow MSC-conditioned medium showed the potential to enhance regeneration of rat periodontal defects and rat bisphosphonate-related osteonecrosis of the jaw (Kawai et al., 2015; Ogata et al., 2015). In periodontal defects, CD31, CD105, and Flk1 positive progenitors occurred more frequently in the conditioned medium group than controls after 2 weeks and regenerated periodontal tissue was found 4 weeks after implantation (Kawai et al., 2015). In the bisphosphonate-related osteonecrosis of the jaw model, conditioned medium resulted in the healing of open alveolar bone sockets in $63 \%$ of the rats (with complete soft tissue coverage and socket bones), compared to the exposed necrotic bone with inflamed soft tissue remaining in the control group (Ogata et al., 2015). 
Histological analyses demonstrated new bone formation and appearance of osteoclasts with conditioned medium treatment, which was significantly higher compared to the non-treatment group, thus indicating that anti-apoptotic and anti-inflammatory effects of conditioned medium regulated the turnover of local bone (Ogata et al., 2015). A related in vitro study indicated that bone marrow MSCs release paracrine factors which directed osteo/odontogenic differentiation of dental pulp cells (Al-Sharabi et al., 2014). Further in vitro studies indicated that bone marrow MSC-conditioned medium promoted osteoclast differentiation and expression of master regulatory transcriptional factors for osteoclastogenesis, as well as showed maintenance of osteoclasts despite the presence of RANKL inhibitors (Ogata et al., 2017). Interestingly, a cytokine mixture composed of recombinant monocyte chemoattractant proteins-1, vascular endothelial growth factor, and insulin-like growth factor-1 in concentrations similar to those found in bone marrow MSC conditioned medium, promoted migration, proliferation, and osteogenic differentiation of rat MSCs in vitro similarly to conditioned medium, and intravenous application improved the healing of medication-related osteonecrosis of the jaw in a rat model (Ogata et al., 2018).

Fujio et al. studied conditioned media from human dental pulp cells cultured in normoxic and hypoxic conditions (Fujio et al., 2017). Significantly higher angiogenic potential of conditioned media from hypoxic compared to normoxic cultures and no enhancement of either conditioned media compared to controls on the mineralization of human fetal osteoblasts were found in vitro. In a mouse distraction osteogenesis model, repeated injections of conditioned medium resulted in increased blood vessel density and higher bone formation compared to the medium control group at 4 weeks (Fujio et al., 2017). In a comparative study of conditioned media from human fetal MSCs, human adult MSCs and rat MSCs, human fetal MSC-conditioned medium showed the highest osteogenic capacity and the lowest immunogenicity in vitro, as well as enhanced bone consolidation after repeated injections in the rat distraction osteogenesis model (Xu et al., 2016). A further in vitro study reported that the secretome of human fetal MSCs ameliorated replicative senescence and enhanced cell proliferation and the osteogenic differentiation potential of human adult MSCs (Wang et al., 2016). Concomitant activation of SIRT1 and FOXO3a expression, upregulation of p21 gene expression, and downregulation of $B A X$ and p53 gene expression were found, and the pre-treatment resulted in restored osteogenic ability of senescent human adult MSCs in a nude mouse ectopic bone formation model (Wang et al., 2016).

Based on the positive outcomes of studies in bone regeneration models, Katagiri et al. reported a first-in-human study and clinical case reports of alveolar bone regeneration using conditioned medium from human bone marrow MSCs (Katagiri et al., 2016). Human bone marrow MSC-conditioned medium was soaked on beta-tricalcium phosphate or on atelocollagen sponge and 8 patients with severe alveolar bone atrophy were treated prior to, or at the same time as dental implant placement. The patients experienced no systemic or local complications and showed early mineralization in the augmented bone according to radiographic evaluations. Calcium phosphate biomaterial structures gradually became indistinct from the surrounding bone 6 months after the surgeries, and biopsies confirmed new bone replacement of the resorbed biomaterial (Katagiri et al., 2016).

\section{MSC-SECRETED EXTRACELLULAR VESICLES FOR BONE REGENERATION}

Growing understanding of MSC intercellular communication via their secretome offers new options for tissue engineering strategies in bone regeneration (Lamichhane et al., 2015). Extracellular vesicles (EVs) are a heterogeneous group of small, lipid-bilayer enclosed, cell-derived particles, exerting effects on fundamental cellular processes in a pleiotropic manner (El Andaloussi et al., 2013). This mechanism is evolutionary conserved from bacteria to humans and plants (Schuh et al., 2019) and was initially considered a means of eliminating unneeded cellular compounds (Johnstone et al., 1987). However, in 1996, Raposo et al. demonstrated that EVs could modulate an adaptive immune response (Raposo et al., 1996) and research from the last two decades has shown that they facilitate intercellular communication, acting as mobile signaling platforms modulating fundamental biological processes in health and disease (Isola and Chen, 2016). Virtually every cell type secretes EVs and they act by the horizontal transfer of proteins, lipids, mRNAs, miRNAs, and other non-coding RNAs, altering the activity of a neighboring or distant target cell (Van Niel et al., 2018). Thereby, the lipid bilayer protects nucleic acids and proteins from degradation in the extracellular environment, allowing their efficient transport. Taken together, these findings have spurred a tremendous amount of effort to exploit EVs as potential therapeutics for immune response modulation and tissue regeneration.

Currently, the term "extracellular vesicles" refers to all types of secreted vesicles released by different cell types under different conditions (Araldi et al., 2012). Based on their biogenesis, two main categories of EVs can be envisioned for therapeutic use: exosomes and microvesicles. Exosomes are rather homogeneous in size $(\sim 40-100 \mathrm{~nm})$ and are generated in the endosome as intraluminal vesicles which subsequently mature to multivesicular endosomes. Cargo is sorted into exosomes by distinct mechanisms resulting in the formation of heterogeneous populations of intraluminal vesicles (Colombo et al., 2014). Sorting either involves ESCRT (endosomal sorting complex required for transport), Alix (or PDCD6IP; programmed cell death 6 interacting protein), and TSG101 (tumor susceptibility gene 101 protein) or takes place via an ESCRT-independent mechanism (reviewed in Van Niel et al., 2018). Finally, exosomes are released into the extracellular space upon fusion of the multivesicular endosomes with the cellular plasma membrane. Some of the commonly used markers to identify exosomes are various tetraspanins (CD63, CD81, and CD9), ALIX, TSG101 (tumor susceptibility gene 101 protein), and flotilin-1. However, a recent study demonstrated that classical tetraspanin-enriched exosomes contain a much more 
limited repertoire of active molecules than has previously been assumed (Jeppesen et al., 2019), highlighting the necessity of suitable protocols for exosome characterization.

Microvesicles (often also referred to as ectosomes or shedding vesicles) represent a rather heterogeneous population of EVs generated by outward budding and subsequent fission of the plasma membrane. Both cargo sorting and subsequent $\mathrm{Ca}^{2+}$. dependent vesicle shedding are regulated by various small GTPases, including members of the ARF (ARF6 and ARF1), Rab20, and Rho (Rac1 and RhoA) families (Tricarico et al., 2017). Microvesicles can range in size from $\sim 100 \mathrm{~nm}$ to $\sim 1 \mu \mathrm{m}$, are rich in phosphatidylserine and are often characterized by the presence of integrins, selectins, and CD40 ligand. Recently, annexin A1 has been proposed as a specific marker for microvesicles which are shed directly from the plasma membrane (Jeppesen et al., 2019). Once EVs are released into the extracellular environment, uptake into target cells takes place either by a receptor-mediated process, internalization by endocytic uptake, or by simple fusion of the cell and vesicle lipid bilayer. However, the unequivocal classification of EVs remains difficult, as the different types share overlapping characteristics and no unique markers are available. Further, current protocols used to purify EVs result in a heterogeneous vesicle population (Willms et al., 2016) and cannot fully exclude a soluble fraction within the purified product, which is why the term "vesicular secretome fraction" has been coined, encompassing both soluble and vesicular components (Gimona et al., 2017).

Several groups provided evidence that EVs are important regulators of stromal cell maintenance (Ratajczak et al., 2006; Quesenberry et al., 2015) and function (Weilner et al., 2016) and it is now widely accepted that much of the efficacy of stromal cell therapies comes from EVs and/or soluble factors (Caplan and Dennis, 2006; Caplan and Correa, 2011). In particular, EVs secreted by MSCs are considered promising candidates for future cell-free regenerative therapies. The paracrine action of MSCs was shown by Gnecchi et al., demonstrating that application of MSC-conditioned medium ameliorated tissue damage in a rodent model of acute myocardial infarction (Gnecchi et al., 2005). Later studies confirmed these results in both pig and mouse models using fractionated MSC secretome preparations (Timmers et al., 2008; Arslan et al., 2013). Since then, the regenerative and immunomodulatory capacity of MSC-derived EVs have been evaluated in several animal disease models, including e.g., kidney and liver injury, lung disease, cartilage repair, hind limb ischemia, ischemic brain injury, and spinal cord injury (reviewed in Harrell et al., 2019).

As MSCs secrete large amounts of EVs (Yeo et al., 2013), EV-based approaches to boost bone regeneration were soon evaluated. As pointed out earlier, in comparison with direct MSC transplantation, MSC-derived EVs appear prima facie safer, as they are devoid of viable cells. Further, systemically applied EV preparations are less likely to be trapped in the lung or liver and are most likely less immunogenic (Lai et al., 2013). Finally, they can be stored for an extended period of time, offering the possibility of an off-the-shelf product for restoration of bone defects (Webber and Clayton, 2013). Indeed, EVs purified from bone marrow MSCs, umbilical cord MSCs, endothelial progenitor cells, and iPSC-MSCs enhanced healing of bone in rodent models (Furuta et al., 2016; Qi et al., 2016; Jia et al., 2019; Zhang et al., 2019). Furuta et al. isolated EVs from human bone marrow MSC-conditioned medium and injected it into femoral fractures in a CD9 negative mouse strain (which produces low levels of EVs) and wild type mice (Furuta et al., 2016). Preparations of EVs contained low levels of bone-repair related cytokines. However, their application accelerated fracture healing compared to control (vehicle treated) animals (Furuta et al., 2016). Repeated injections of EVs prepared from human ESC-MSCs similarly promoted the regeneration of osteochondral defects in a rat femur model (Zhang et al., 2016b) and enhanced bone regeneration was found in a rat distraction osteogenesis model with injections of EVs prepared from rat endothelial progenitors (Jia et al., 2019).

More recently, MSC-EVs combined with various scaffold materials generated bone in vivo in ectopic sites (Xie et al., 2017) and successfully promoted bone repair in rodent calvarial bone defects (Qi et al., 2016; Qin et al., 2016; Li et al., 2018). Ideally, biocompatible scaffolds should degrade at an appropriate rate and facilitate the controlled release of the extracellular vesicles, as mere loading results in a burst release and might be less efficient in exerting pro-regenerative effects. Qi et al. showed in a calvarial defect model, established in osteoporotic rats, that treatment with tricalcium phosphate scaffolds loaded with EVs prepared from hiPSC-MSCs repaired bone defects through enhanced angiogenesis and osteogenesis (Qi et al., 2016). More recently, Li et al. reported that human adipose MSC-derived EVs immobilized onto poly-lactic-co-glycolic acid scaffolds exhibited a slow release profile in vitro and enhanced bone regeneration in mouse calvarial defects after 6 weeks (Li et al., 2018).

However, the molecular and cellular mechanisms underpinning the osteogenic effect of EVs remain poorly defined and they are certainly cell- and tissue context-dependent (Harrell et al., 2019). Potentially, they can be attributed to a protective effect in necrotic and ischemic environments (Liu et al., 2017), recruitment of endogenous MSCs (Osugi et al., 2012; Furuta et al., 2016), and HIF-1alpha-dependent pro-angiogenic activity (Qi et al., 2016; Zhang et al., 2019). In addition, MSC-EVs seem to directly promote osteogenic differentiation, in part by activating the PI3K/AKT signaling pathway (Zhang et al., 2016a) and via the activity of miRNA-196a released from the EVs (Qin et al., 2016). In general, MSC-derived extracellular vesicles have been shown to exert anti-inflammatory properties by inducing high levels of anti-inflammatory proteins, while concomitantly attenuating pro-inflammatory cytokines in THP-1 monocytes in vitro and inducing regulatory $\mathrm{T}$ cells in vivo (Zhang et al., 2014). Taken together, MSC-EVs elicit pleiotropic effects, promoting bone repair. However, it is important to note that the characteristics of the microenvironment influence the function of EVs produced by these cells (Huang and Feng, 2017). Along these lines, Zhu et al. demonstrated that the pro-angiogenic and osteogenic actions of bone marrow MSC-EVs are impaired in type-1 diabetes (Zhu et al., 2019). Therefore, it is imperative to choose appropriate cell sources for EV production for future therapeutic strategies. Taken together, EV-based, cell-free therapies appear to be a promising strategy to repair bone tissue. 
However, to ensure comparability between preclinical studies and to allow future translation into the clinic, EV purification and characterization protocols urgently need to be harmonized (Witwer et al., 2019).

\section{PRODUCTION OF MSCS, SECRETOME, AND EXTRACELLULAR VESICLES FOR CLINICAL USE}

Production of MSCs for clinical use requires appropriate laboratory procedures adhering to GMP regulations. These procedures have been reported previously by several groups for bone marrow MSCs (Schallmoser et al., 2009; Fekete et al., 2012). Similarly, the manufacturing of MSC-derived therapeutic secretome and EVs for clinical testing requires GMP-compliant strategies, and several groups focused on establishing such protocols (Andriolo et al., 2018; Mendt et al., 2018; Rohde et al., 2019). Existing GMP protocols for MSC expansion can be largely adopted for the first step in secretome/EV production and standard operating procedures can be expanded by the concomitant processing steps of the conditioned medium. Overall, the therapeutic secretome/EV field benefits at this point from the experience gained from MSC manufacturing for clinical applications as well as from the ample experience available from virus-like particle enrichment. In an excellent overview on the current status of EV manufacturing, Whitford and Guterstam (2019) indicated that the technologies and knowledge for GMPcompliant EV production are at hand. However, some adaptation and fine tuning is still required. For instance, it should be noted that large scale production of therapeutic MSCs in order to obtain significant batch sizes of either cells or EVs for preclinical and clinical testing may alter the physiological state of the MSCs. The influence of cell passage number on the therapeutic potential of MSC-derived EVs has been questioned at least for adipose MSCs (Serra et al., 2018). Furthermore, the use of serum-free medium can cause changes in exosome biology and cargo sorting, and the use of coatings (e.g., fibronectin, gelatin) alters the profile of MSC adhesion and mechanotransduction and automatically violates a central requirement for defining MSCs, namely plastic adherence (Brindley et al., 2011; Whitford and Guterstam, 2019).

Bioreactor systems and associated analytical approaches have been studied for scale-up and a more efficient, reproducible, safe and cost-effective production of MSCs and secretome compared to static culture (Carmelo et al., 2015; Mizukami et al., 2019). Carmelo et al. developed a xeno-free microcarrier-based stirred culture system for scalable expansion of bone marrow and adipose MSCs. Their secretome analysis suggested a priming effect of stirred culture conditions toward potentially increased production of specific cytokines by MSCs (Carmelo et al., 2015). Similarly, a study by Teixeira et al. indicated that culture of bone marrow MSCs on microcarriers using computer-controlled suspension bioreactors enhanced the neuroregulatory profile of the secretome compared to static cultures (Teixeira et al., 2016). Secretory profiles of the MSCs can also be modulated by the surface structure of the microenvironment (Leuning et al., 2018), pointing further to the enhanced potential of engineered threedimensional culture environment for optimizing MSC-derived therapeutic products.

\section{FUTURE DIRECTIONS AND CHALLENGES FOR MSC-BASED BONE REGENERATION APPROACHES}

Within the field of bone regeneration, there is a clear need for new cell-based or cell-free therapies for a number of conditions in which bone does not heal, resulting is significant morbidity and burden for the patients. At this time, several MSC-based therapies have reached the stage of clinical trials, but none of the approaches has been accepted in the clinic as the standard of care (Stegemann et al., 2014). Additional research is needed to advance our mechanistic understanding of various cell-, EV-, and tissue engineering-based therapies within specific clinical indications.

For MSC-based cell therapies, some of the currently registered clinical studies are starting to address the questions of dosing, the use of autologous vs. allogeneic cells, and efficacy compared to standard treatments using autologous bone grafts. However, many challenges remain in the standardization, quality control, and potency evaluation of MSC-based cell therapies, as well as in the scale-up, GMP manufacturing, and logistics, in particular when autologous MSCs are used. In addition to inter-patient variability due to age, health, and various risk factors, inherent differences between MSCs from various tissue sources present specific advantages and disadvantages, such as the potential to be harvested in high or low yields, surgical procedures and donor site morbidity, potential of use with minimal intra-surgical manipulation/preparation of the cells, the need for additional cell storage and culture of the cells to increase their numbers, coapplication of signals to promote cell phenotype/differentiation, local vs. systemic delivery via injections or in combination with scaffolds (i.e., tissue-engineered therapies). For certain indications, e.g., complex facial bone defects, extended in vitro or in vivo engineering of viable bone substitutes might be required to provide appropriate architecture as well as mechanical properties for defect stabilization and loading, which are key for successful healing. For others, MSC injections or co-application with bone substitute materials might provide the critical components required for successful outcomes.

Due to these complexities with viable cells and tissue transplantation, a number of investigations have also focused on enhanced mobilization and homing of endogenous cells (which has not been extensively investigated in the clinic) (Yao and Lane, 2015; Karlsson et al., 2016; Yao et al., 2016) and on novel, secretome-based therapeutic approaches. Whereas clinical translation of the whole secretome might prove challenging as well, re-constitution of major secreted growth factor components (e.g., by using recombinant proteins) in concentrations similar to those in the MSC secretome might recapitulate the therapeutic effects, as was recently demonstrated (Ogata et al., 2018). Of note, repeated applications of conditioned media were used in several studies to achieve the therapeutic effects, in contrast to single 
applications in the case of cell- and tissue-engineering-based therapeutic approaches. Surviving transplanted cells/tissues will be exposed to the effects of the local environment in the defect and might change their functions as a result. In contrast, preparation of therapeutic secretome might incorporate in vitro culture modifications to modulate the composition of released components.

Therapies based on EVs face similar problems as cell therapies in translating the promising research data into well-defined clinical trials and subsequent applications to patients. A central issue in the field is the standardization of manufacturing and analytic processes. A prerequisite for this advancement seems to be the awareness that any cell-derived $\mathrm{EV}$ product will always comprise of a heterogeneous mixture of extracellular vesicles and in most cases also of co-purifying soluble components. While this heterogeneity may be more of a concern for naive, unmanipulated MSC-EV preparations, loading and engineering of EV products to contain specific signals (Sutaria et al., 2017) might be less affected, with a greater focus on the characterization of the active component (e.g., siRNAs or engineered proteins) and its therapeutic potential.

Intuitively, the discussion on the best cell source for use in bone regeneration will always consider that cells that perform better in in vitro differentiation assays toward osteogenic lineage may be better suited for the manufacturing of EVs that support or enhance bone healing. It must be emphasized though, that these assays are highly artificial and the link between in vitro cell differentiation potential and the regenerative potential of cell-derived EVs must be further evaluated. Current efforts in the EV community are focused on determining the best producer cell source, on potential modes of action, and on standardization of physico-chemical assays and analytical devices for functional EV characterization. At the present time, analytical methods that are specifically tailored to characterize therapeutic EVs are largely missing. Nanoparticle tracking analysis is capable of determining the total number of particles in the heterogeneous (secretome) solution, but neither the particle size nor the particle number can currently predict the functionality of the product. Cell-based potency assays are difficult to establish to the level of GMP compliance and will have to be designed specifically for each clinical indication.

There is also no current consensus on the best method to expand the producer MSCs (two-dimensional vs. threedimensional culture, batch-feed vs. stirred tank bioreactor, serum supplemented vs. serum free/defined medium) or to enrich/purify EVs or secretome. Therefore, application for clinical trials cannot rely on or reference to already approved investigational new drug/investigational medicinal products. This is well-reflected by the mere four interventional studies with EVs that are listed at clinicaltrials.gov. To some, the

\section{REFERENCES}

Al-Sharabi, N., Xue, Y., Fujio, M., Ueda, M., Gjerde, C., Mustafa, K., et al. (2014). Bone marrow stromal cell paracrine factors direct osteo/odontogenic current classification of EV-containing therapeutic substances as biologicals by both EMA and FDA seems to be an advantage, since ATMP regulations do not apply. It remains to be seen, however, how the regulatory agencies deal with the application on a case-by-case basis in the absence of clear and binding regulations.

Finally, prospective manufacturers of EV therapeutics have to take into consideration that EV-based products for improved bone healing and regeneration aim, for the most part, at non-lifethreatening medical indications. Irrespective of the considerable benefit for the patient and the health care system, this fact impacts the possible pricing of the product and thus the total manufacturing cost. For instance, the current financial requirement for available CAR-T cell therapy $(430,000 \$$ US) is an extreme example of the costs of cell-based therapy. Therapies based on EVs toward bone healing should look more at costs in the range of $1,000-2,000 \$$ US to make the treatment both attractive and suitable for refund by the health insurance providers. This, however, will again demand precise calculations of the cost of goods and manufacturing costs, as well as for costs for testing, release, and storage. In this respect, batch size and dosing once again take center stage and must be considered in the development of a GMP-compliant manufacturing process for $\mathrm{EV}$ therapeutics and EV-enriched secretome.

In conclusion, further advancements in the science and translation of MSC-based therapies are required, and this growing body of knowledge, in conjunction with the improved identification of clinical indications and patients best suited for these treatments, will be key to creating therapies that will be consistently more successful than current treatments, while also being cost effective and marketable.

\section{AUTHOR CONTRIBUTIONS}

All authors listed have made a substantial, direct and intellectual contribution to the work, and approved it for publication.

\section{FUNDING}

This work was supported by the European Regional Development Fund Interreg V-A Italia-Austria 2014-2020 (Project EXOTHERA IT-AT 1036), the Project ExtraNeu from the State of Salzburg, Austria, and the project RejuvenateBone funding from the European Union's Horizon 2020 Research and Innovation Programme under the Marie Sklodowska-Curie grant agreement No. 657716.

\section{ACKNOWLEDGMENTS}

The authors would like to thank James Ferguson for the English language editing and Alain Brisson for the EV image acquisition.

differentiation of dental pulp cells. Tissue Eng. Part A 20, 3063-3072. doi: 10.1089/ten.tea.2013.0718

Alves, H., van Ginkel, J., Groen, N., Hulsman, M., Mentink, A., Reinders, M., et al. (2012). A mesenchymal stromal cell gene signature 
for donor age. PLoS ONE 7:e42908. doi: 10.1371/journal.pone.00 42908

Ando, Y., Matsubara, K., Ishikawa, J., Fujio, M., Shohara, R., Hibi, H., et al. (2014). Stem cell-conditioned medium accelerates distraction osteogenesis through multiple regenerative mechanisms. Bone 61, 82-90. doi: 10.1016/j.bone.2013.12.029

Andriolo, G., Provasi, E., Lo Cicero, V., Brambilla, A., Soncin, S., Torre, T., et al. (2018). Exosomes from human cardiac progenitor cells for therapeutic applications: development of a GMP-grade manufacturing method. Front. Physiol. 9:1169. doi: 10.3389/fphys.2018.01169

Araldi, E., Krämer-Albers, E.-M., 't Hoen, E. N., Peinado, H., Psonka-Antonczyk, K. M., Rao, P., et al. (2012). International Society for Extracellular Vesicles: first annual meeting, April 17-21, 2012: ISEV-2012. J. Extracell. Vesicles 1:19995. doi: 10.3402/jev.vli0.19995

Arinzeh, T. L., Peter, S. J., Archambault, M. P., Van Den Bos, C., Gordon, S., Kraus, K., et al. (2003). Allogeneic mesenchymal stem cells regenerate bone in a critical-sized canine segmental defect. J. Bone Jt. Surg. 85, 1927-1935. doi: 10.2106/00004623-200310000-00010

Arslan, F., Lai, R. C., Smeets, M. B., Akeroyd, L., Choo, A., Aguor, E. N. E., et al. (2013). Mesenchymal stem cell-derived exosomes increase ATP levels, decrease oxidative stress and activate PI3K/Akt pathway to enhance myocardial viability and prevent adverse remodeling after myocardial ischemia/reperfusion injury. Stem Cell Res. 10, 301-312. doi: 10.1016/j.scr.2013.01.002

Baker, N., Boyette, L. B., and Tuan, R. S. (2015). Characterization of bone marrow-derived mesenchymal stem cells in aging. Bone 70, 37-47. doi: 10.1016/j.bone.2014.10.014

Baksh, D., Yao, R., and Tuan, R. S. (2007). Comparison of proliferative and multilineage differentiation potential of human mesenchymal stem cells derived from umbilical cord and bone marrow. Stem Cells 25, 1384-1392. doi: 10.1634/stemcells.2006-0709

Barabaschi, G. D. G., Manoharan, V., Li, Q., and Bertassoni, L. E. (2015). Engineering pre-vascularized scaffolds for bone regeneration. Adv. Exp. Med. Biol. 881, 79-94. doi: 10.1007/978-3-319-22345-2_5

Becquart, P., Cambon-Binder, A., Monfoulet, L. E., Bourguignon, M., Vandamme, K., Bensidhoum, M., et al. (2012). Ischemia is the prime but not the only cause of human multipotent stromal cell death in tissue-engineered constructs in vivo. Tissue Eng. Part A 18, 2084-2094. doi: 10.1089/ten.tea.2011.0690

Bernhard, J., Ferguson, J., Rieder, B., Heimel, P., Nau, T., Tangl, S., et al. (2017). Tissue-engineered hypertrophic chondrocyte grafts enhanced long bone repair. Biomaterials 139, 202-212. doi: 10.1016/j.biomaterials.2017.05.045

Bhattacharjee, A., Kuiper, J. H., Roberts, S., Harrison, P. E., Cassar-Pullicino, V. N., Tins, B., et al. (2019). Predictors of fracture healing in patients with recalcitrant nonunions treated with autologous culture expanded bone marrow-derived mesenchymal stromal cells. J. Orthop. Res. 37, 1303-1309. doi: $10.1002 /$ jor. 24184

Bhumiratana, S., Bernhard, J. C., Alfi, D. M., Yeager, K., Eton, R. E., Bova, J., et al. (2016). Tissue-engineered autologous grafts for facial bone reconstruction. Sci. Transl. Med. 8:343ra83. doi: 10.1126/scitranslmed.aad5904

Bianco, P., Riminucci, M., Gronthos, S., and Robey, P. G. (2001). Bone marrow stromal stem cells: nature, biology, and potential applications. Stem Cells 19, 180-192. doi: 10.1634/stemcells.19-3-180

Bilic, J., and Izpisua Belmonte, J. C. (2012). Concise review: induced pluripotent stem cells versus embryonic stem cells: close enough or yet too far apart? Stem Cells 30, 33-41. doi: 10.1002/stem.700

Bock, C., Kiskinis, E., Verstappen, G., Gu, H., Boulting, G., Smith, Z. D., et al. (2011). Reference maps of human es and ips cell variation enable high-throughput characterization of pluripotent cell lines. Cell 144, 439-452. doi: 10.1016/j.cell.2010.12.032

Börger, V., Bremer, M., Ferrer-Tur, R., Gockeln, L., Stambouli, O., Becic, A., et al. (2017). Mesenchymal stem/stromal cell-derived extracellular vesicles and their potential as novel immunomodulatory therapeutic agents. Int. J. Mol. Sci. 18:E1450. doi: 10.3390/ijms18071450

Borrelli, J., Pape, C., Hak, D., Hsu, J., Lin, S., Giannoudis, P., et al. (2012). Physiological challenges of bone repair. J. Orthop. Trauma 26, 708-711. doi: 10.1097/BOT.0b013e318274da8b

Bourin, P., Bunnell, B. A., Casteilla, L., Dominici, M., Katz, A. J., March, K. L., et al. (2013). Stromal cells from the adipose tissue-derived stromal vascular fraction and culture expanded adipose tissue-derived stromal/stem cells: a joint statement of the International Federation for Adipose Therapeutics and Science (IFATS) and the International So. Cytotherapy 15, 641-648. doi: 10.1016/j.jcyt.2013.02.006

Braccini, A., Wendt, D., Farhadi, J., Schaeren, S., Heberer, M., and Martin, I. (2007). The osteogenicity of implanted engineered bone constructs is related to the density of clonogenic bone marrow stromal cells. J. Tissue Eng. Regen. Med. 1, 60-65. doi: 10.1002/term.11

Brennan, M. A., Renaud, A., Guilloton, F., Mebarki, M., Trichet, V., Sensebé, L., et al. (2017). Inferior in vivo osteogenesis and superior angiogeneis of human adipose tissue: a comparison with bone marrow-derived stromal stem cells cultured in xeno-free conditions. Stem Cells Transl. Med. 6, 2160-2172. doi: 10.1002/sctm.17-0133

Brindley, D., Moorthy, K., Lee, J. H., Mason, C., Kim, H. W., and Wall, I. (2011). Bioprocess forces and their impact on cell behavior: implications for bone regeneration therapy. J. Tissue Eng. 2, 1-13. doi: 10.4061/2011/620247

Brown, C., McKee, C., Bakshi, S., Walker, K., Hakman, E., Halassy, S., et al. (2019). Mesenchymal stem cells: cell therapy and regeneration potential. J. Tissue Eng. Regen. Med. 13, 1738-1755. doi: 10.1002/term.2914

Bruder, S. P., and Fox, B. S. (1999). Tissue engineering of bone: cell based strategies. Clin. Orthop. Relat. Res. 367, S68-S83. doi: 10.1097/00003086-199910001-00008

Bruder, S. P., Kurth, A. A., Shea, M., Hayes, W. C., Jaiswal, N., and Kadiyala, S. (1998). Bone regeneration by implantation of purified, cultureexpanded human mesenchymal stem cells. J. Orthop. Res. 16, 155-162. doi: 10.1002/jor.1100160202

Caplan, A. I. (2008). All MSCs are pericytes? Cell Stem Cell 3, 229-230. doi: 10.1016/j.stem.2008.08.008

Caplan, A. I. (2017). Mesenchymal stem cells: time to change the name! Stem Cells Transl. Med. 6, 1445-1451. doi: 10.1002/sctm.17-0051

Caplan, A. I., and Correa, D. (2011). The MSC: an injury drugstore. Cell Stem Cell 9, 11-15. doi: 10.1016/j.stem.2011.06.008

Caplan, A. I., and Dennis, J. E. (2006). Mesenchymal stem cells as trophic mediators. J. Cell. Biochem. 98, 1076-1084. doi: 10.1002/jcb.20886

Caralla, T., Joshi, P., Fleury, S., Luangphakdy, V., Shinohara, K., Pan, H., et al. (2013). In vivo transplantation of autogenous marrow-derived cells following rapid intraoperative magnetic separation based on hyaluronan to augment bone regeneration. Tissue Eng. Part A 19, 125-134. doi: 10.1089/ten.tea.2011.0622

Carmelo, J. G., Fernandes-Platzgummer, A., Diogo, M. M., da Silva, C. L., and Cabral, J. M. S. (2015). A xeno-free microcarrier-based stirred culture system for the scalable expansion of human mesenchymal stem/stromal cells isolated from bone marrow and adipose tissue. Biotechnol. J. 10, 1235-1247. doi: 10.1002/biot.201400586

Castillo-Cardiel, G., López-Echaury, A. C., Saucedo-Ortiz, J. A., FuentesOrozco, C., Michel-Espinoza, L. R., Irusteta-Jiménez, L., et al. (2017). Bone regeneration in mandibular fractures after the application of autologous mesenchymal stem cells, a randomized clinical trial. Dent. Traumatol. 33, 38-44. doi: 10.1111/edt.12303

Chadid, T., Morris, A., Surowiec, A., Robinson, S., Sasaki, M., Galipeau, J., et al. (2018). Reversible secretome and signaling defects in diabetic mesenchymal stem cells from peripheral arterial disease patients. J. Vasc. Surg. 68, 137S-151S.e2. doi: 10.1016/j.jvs.2018.05.223

Chan, C. K. F., Gulati, G. S., Sinha, R., Tompkins, J. V., Lopez, M., Carter, A. C., et al. (2018). Identification of the human skeletal stem cell. Cell 175, 43-56.e21. doi: 10.1016/j.cell.2018.07.029

Chase, L. G., Lakshmipathy, U., Solchaga, L. A., Rao, M. S., and Vemuri, M. C. (2010). A novel serum-free medium for the expansion of human mesenchymal stem cells. Stem Cell Res. Ther. 1:8. doi: 10.1186/scrt8

Chen, L., Tredget, E. E., Wu, P. Y. G., Wu, Y., and Wu, Y. (2008). Paracrine factors of mesenchymal stem cells recruit macrophages and endothelial lineage cells and enhance wound healing. PLOS ONE 3:e1886. doi: 10.1371/journal.pone.0001886

Chuenjitkuntaworn, B., Osathanon, T., Nowwarote, N., Supaphol, P., and Pavasant, P. (2016). The efficacy of polycaprolactone/hydroxyapatite scaffold in combination with mesenchymal stem cells for bone tissue engineering. $J$. Biomed. Mater. Res. 104, 264-271. doi: 10.1002/jbm.a.35558

Chung, C. G., James, A. W., Asatrian, G., Chang, L., Nguyen, A., Le, K., et al. (2015). Human perivascular stem cell-based bone graft 
substitute induces rat spinal fusion. Stem Cells Transl. Med. 4, 538-538. doi: 10.5966/sctm.2014-0027erratum

Churchman, S. M., Boxall, S. A., McGonagle, D., and Jones, E. A. (2017). Predicting the remaining lifespan and cultivation-related loss of osteogenic capacity of bone marrow multipotential stromal cells applicable across a broad donor age range. Stem Cells Int. 2017:6129596. doi: 10.1155/2017/6129596

Cohn Yakubovich, D., Sheyn, D., Bez, M., Schary, Y., Yalon, E., Sirhan, A., et al. (2017). Systemic administration of mesenchymal stem cells combined with parathyroid hormone therapy synergistically regenerates multiple rib fractures. Stem Cell Res. Ther. 8:51. doi: 10.1186/s13287-017-0502-9

Colombo, M., Raposo, G., and Théry, C. (2014). Biogenesis, secretion, and intercellular interactions of exosomes and other extracellular vesicles. Annu. Rev. Cell Dev. Biol. 30, 255-289. doi: 10.1146/annurev-cellbio-101512-122326

Correia, C., Bhumiratana, S., Yan, L. P., Oliveira, A. L., Gimble, J. M., Rockwood, D., et al. (2012). Development of silk-based scaffolds for tissue engineering of bone from human adipose-derived stem cells. Acta Biomater. 8, 2483-2492. doi: 10.1016/j.actbio.2012.03.019

Crisan, M., Yap, S., Casteilla, L., Chen, C. W., Corselli, M., Park, T. S., et al. (2008). A perivascular origin for mesenchymal stem cells in multiple human organs. Cell Stem Cell 3, 301-313. doi: 10.1016/j.stem.2008.07.003

De Peppo, G. M., Marcos-Campos, I., Kahler, D. J., Alsalman, D., Shang, L., Vunjak-Novakovic, G., et al. (2013). Engineering bone tissue substitutes from human induced pluripotent stem cells. Proc. Natl. Acad. Sci. U.S.A. 110, 8680-8685. doi: 10.1073/pnas.1301190110

De Peppo, G. M., and Marolt, D. (2013). Modulating the biochemical and biophysical culture environment to enhance osteogenic differentiation and maturation of human pluripotent stem cell-derived mesenchymal progenitors. Stem Cell Res. Ther. 4:106. doi: 10.1186/scrt317

Ding, M., Henriksen, S. S., Wendt, D., and Overgaard, S. (2016). An automated perfusion bioreactor for the streamlined production of engineered osteogenic grafts. J. Biomed. Mater. Res. B Appl. Biomater. 104, 532-537. doi: $10.1002 / j b m . b .33407$

Dominici, M., Le Blanc, K., Mueller, I., Slaper-Cortenbach, I., Marini, F. C., Krause, D. S., et al. (2006). Minimal criteria for defining multipotent mesenchymal stromal cells. The International Society for Cellular Therapy position statement. Cytotherapy 8, 315-317. doi: 10.1080/146532406008 55905

Dubey, N. K., Mishra, V. K., Dubey, R., Deng, Y. H., Tsai, F. C., and Deng, W. P. (2018). Revisiting the advances in isolation, characterization and secretome of adipose-derived stromal/stem cells. Int. J. Mol. Sci. 19:E2200. doi: $10.3390 /$ ijms 19082200

Dufrane, D. (2017). Impact of age on human adipose stem cells for bone tissue engineering. Cell Transplant. 26, 1496-1504. doi: 10.1177/0963689717721203

Dupont, K. M., Sharma, K., Stevens, H. Y., Boerckel, J. D., García, A. J., and Guldberg, R. E. (2010). Human stem cell delivery for treatment of large segmental bone defects. Proc. Natl. Acad. Sci. U.S.A. 107, 3305-3310. doi: 10.1073/pnas.0905444107

Ekegren, C. L., Edwards, E. R., de Steiger, R., and Gabbe, B. J. (2018). Incidence, costs and predictors of non-union, delayed union and mal-union following long bone fracture. Int. J. Environ. Res. Public Health 15:E2845. doi: 10.3390/ijerph15122845

El Andaloussi, S., Mäger, I., Breakefield, X. O., and Wood, M. J. A. (2013). Extracellular vesicles: Biology and emerging therapeutic opportunities. Nat. Rev. Drug Discov. 12, 347-357. doi: 10.1038/nrd3978

Emadedin, M., Karimi, S., Karimi, A., Labibzadeh, N., Niknejadi, M., Baharvand, H., et al. (2019). Autologous bone marrow-derived CD133 cells with core decompression as a novel treatment method for femoral head osteonecrosis: a pilot study. Cytotherapy 21, 107-112. doi: 10.1016/j.jcyt.2018.10.005

Emadedin, M., Labibzadeh, N., Fazeli, R., Mohseni, F., Hosseini, S. E., Moghadasali, R., et al. (2017). Percutaneous autologous bone marrowderived mesenchymal stromal cell implantation is safe for reconstruction of human lower limb long bone atrophic nonunion. Cell J. 19, 159-165. doi: $10.22074 /$ cellj.2016.4866

Epple, C., Haumer, A., Ismail, T., Lunger, A., Scherberich, A., Schaefer, D. J., et al. (2019). Prefabrication of a large pedicled bone graft by engineering the germ for de novo vascularization and osteoinduction. Biomaterials 192, 118-127. doi: 10.1016/j.biomaterials.2018.11.008
Fekete, N., Rojewski, M. T., Fürst, D., Kreja, L., Ignatius, A., Dausend, J., et al. (2012). GMP-compliant isolation and large-scale expansion of bone marrowderived MSC. PLoS ONE 7:e43255. doi: 10.1371/journal.pone.0043255

Forrestal, D. P., Klein, T. J., and Woodruff, M. A. (2017). Challenges in engineering large customized bone constructs. Biotechnol. Bioeng. 114, 1129-1139. doi: 10.1002/bit.26222

Friedenstein, A. J., Chailakhyan, R. K., and Gerasimov, U. V. (1987). Bone marrow osteogenic stem cells: in vitro cultivation and transplantation in diffusion chambers. Cell Prolif. 20, 263-272. doi: 10.1111/j.1365-2184.1987.tb01309.x

Frobel, J., Hemeda, H., Lenz, M., Abagnale, G., Joussen, S., Denecke, B., et al. (2014). Epigenetic rejuvenation of mesenchymal stromal cells derived from induced pluripotent stem cells. Stem Cell Rep. 3, 414-422. doi: $10.1016 /$ j.stemcr.2014.07.003

Frohlich, M., Grayson, W., Wan, L., Marolt, D., Drobnic, M., and VunjakNovakovic, G. (2008). Tissue engineered bone grafts: biological requirements, tissue culture and clinical relevance. Curr. Stem Cell Res. Ther. 3, 254-264. doi: $10.2174 / 157488808786733962$

Fröhlich, M., Grayson, W. L., Marolt, D., Gimble, J. M., Kregar-Velikonja, N., and Vunjak-Novakovic, G. (2010). Bone grafts engineered from human adiposederived stem cells in perfusion bioreactor culture. Tissue Eng. Part A 16, 179-189. doi: 10.1089/ten.tea.2009.0164

Fujio, M., Xing, Z., Sharabi, N., Xue, Y., Yamamoto, A., Hibi, H., et al. (2017). Conditioned media from hypoxic-cultured human dental pulp cells promotes bone healing during distraction osteogenesis. J. Tissue Eng. Regen. Med. 11, 2116-2126. doi: 10.1002/term.2109

Furuta, T., Miyaki, S., Ishitobi, H., Ogura, T., Kato, Y., Kamei, N., et al. (2016). Mesenchymal stem cell-derived exosomes promote fracture healing in a mouse model. Stem Cells Transl. Med. 5, 1620-1630. doi: 10.5966/sctm.2015-0285

Ganguly, P., El-Jawhari, J. J., Giannoudis, P. V., Burska, A. N., Ponchel, F., and Jones, E. A. (2017). Age-related changes in bone marrow mesenchymal stromal cells: a potential impact on osteoporosis and osteoarthritis development. Cell Transplant. 26, 1520-1529. doi: 10.1177/0963689717721201

Geuze, R. E., Prins, H. J., Öner, F. C., Van Der Helm, Y. J. M., Schuijff, L. S., Martens, A. C., et al. (2010). Luciferase labeling for multipotent stromal cell tracking in spinal fusion versus ectopic bone tissue engineering in mice and rats. Tissue Eng. Part A 16, 3343-3351. doi: 10.1089/ten.tea.2009.0774

Ghasemzadeh, M., Hosseini, E., Ahmadi, M., Kamalizad, M., and Amirizadeh, N. (2018). Comparable osteogenic capacity of mesenchymal stem or stromal cells derived from human amnion membrane and bone marrow. Cytotechnology 70 , 729-739. doi: 10.1007/s10616-017-0177-1

Giannoni, P., Scaglione, S., Daga, A., Ilengo, C., Cilli, M., and Quarto, R. (2010). Short-time survival and engraftment of bone marrow stromal cells in an ectopic model of bone regeneration. in Tissue Eng. Part A, 489-499. doi: 10.1089/ten.tea.2009.0041

Gimble, J. M., Katz, A. J., and Bunnell, B. A. (2007). Adipose-derived stem cells for regenerative medicine. Circ. Res. 100, 1249-60. doi: 10.1161/01.RES.0000265074.83288.09

Gimona, M., Pachler, K., Laner-Plamberger, S., Schallmoser, K., and Rohde, E. (2017). Manufacturing of human extracellular vesicle-based therapeutics for clinical use. Int. J. Mol. Sci. 18:E1190. doi: 10.3390/ijms18061190

Gjerde, C., Mustafa, K., Hellem, S., Rojewski, M., Gjengedal, H., Yassin, M. A., et al. (2018). Cell therapy induced regeneration of severely atrophied mandibular bone in a clinical trial. Stem Cell Res. Ther. 9:213. doi: 10.1186/s13287-018-0951-9

Gnecchi, M., He, H., Liang, O. D., Melo, L. G., Morello, F., Mu, H., et al. (2005). Paracrine action accounts for marked protection of ischemic heart by Akt-modified mesenchymal stem cells [2]. Nat. Med. 11, 367-368. doi: 10.1038/nm0405-367

Gómez-Barrena, E., Rosset, P., Gebhard, F., Hernigou, P., Baldini, N., Rouard, H., et al. (2019). Feasibility and safety of treating non-unions in tibia, femur and humerus with autologous, expanded, bone marrow-derived mesenchymal stromal cells associated with biphasic calcium phosphate biomaterials in a multicentric, non-comparative trial. Biomaterials 196, 100-108. doi: 10.1016/j.biomaterials.2018.03.033

Gómez-Barrena, E., Rosset, P., Lozano, D., Stanovici, J., Ermthaller, C., and Gerbhard, F. (2015). Bone fracture healing: cell therapy in delayed unions and nonunions. Bone 70, 93-101. doi: 10.1016/j.bone.2014.07.033 
Granero-Moltó, F., Weis, J. A., Miga, M. I., Landis, B., Myers, T. J., O’Rear, L., et al. (2009). Regenerative effects of transplanted mesenchymal stem cells in fracture healing. Stem Cells 27, 1887-1898. doi: 10.1002/stem.103

Grayson, W. L., Bhumiratana, S., Cannizzaro, C., Chao, P. H. G., Lennon, D. P., Caplan, A. I., et al. (2008). Effects of initial seeding density and fluid perfusion rate on formation of tissue-engineered bone. Tissue Eng. Part A. 14, 1809-1820. doi: 10.1089/ten.tea.2007.0255

Grayson, W. L., Bunnell, B. A., Martin, E., Frazier, T., Hung, B. P., and Gimble, J. M. (2015). Stromal cells and stem cells in clinical bone regeneration. Nat. Rev. Endocrinol. 11, 140-150. doi: 10.1038/nrendo.2014.234

Grayson, W. L., Fröhlich, M., Yeager, K., Bhumiratana, S., Chan, M. E., Cannizzaro, C., et al. (2010). Engineering anatomically shaped human bone grafts. Proc. Natl. Acad. Sci. U.S.A. 107, 3299-3304. doi: 10.1073/pnas.0905439106

Grayson, W. L., Marolt, D., Bhumiratana, S., Fröhlich, M., Guo, X. E., and Vunjak-Novakovic, G. (2011). Optimizing the medium perfusion rate in bone tissue engineering bioreactors. Biotechnol. Bioeng. 108, 1159-1170. doi: 10.1002/bit.23024

Gruber, R., Koch, H., Doll, B. A., Tegtmeier, F., Einhorn, T. A., and Hollinger, J. O. (2006). Fracture healing in the elderly patient. Exp. Gerontol. 41, 1080-1093. doi: 10.1016/j.exger.2006.09.008

Guan, M., Yao, W., Liu, R., Lam, K. S., Nolta, J., Jia, J., et al. (2012). Directing mesenchymal stem cells to bone to augment bone formation and increase bone mass. Nat. Med. 18, 456-462. doi: 10.1038/nm.2665

Güven, S., Mehrkens, A., Saxer, F., Schaefer, D. J., Martinetti, R., Martin, I., et al. (2011). Engineering of large osteogenic grafts with rapid engraftment capacity using mesenchymal and endothelial progenitors from human adipose tissue. Biomaterials 32, 5801-5809. doi: 10.1016/j.biomaterials.2011.04.064

Harrell, C. R., Fellabaum, C., Jovicic, N., Djonov, V., Arsenijevic, N., and Volarevic, V. (2019). Molecular mechanisms responsible for therapeutic potential of mesenchymal stem cell-derived secretome. Cells 8:467. doi: 10.3390/cells 8050467

Hauzeur, J. P., De Maertelaer, V., Baudoux, E., Malaise, M., Beguin, Y., and Gangji, V. (2018). Inefficacy of autologous bone marrow concentrate in stage three osteonecrosis: a randomized controlled double-blind trial. Int. Orthop. 42, 1429-1435. doi: 10.1007/s00264-017-3650-8

Hernigou, P., and Beaujean, F. (2002). Treatment of osteonecrosis with autologous bone marrow grafting. Clin. Orthop. Relat. Res. 405, 14-23. doi: 10.1097/00003086-200212000-00003

Hernigou, P., Dubory, A., Homma, Y., Guissou, I., Flouzat Lachaniette, C. H., Chevallier, N., et al. (2018). Cell therapy versus simultaneous contralateral decompression in symptomatic corticosteroid osteonecrosis: a thirty year follow-up prospective randomized study of one hundred and twenty five adult patients. Int. Orthop. 42, 1639-1649. doi: 10.1007/s00264-018-3941-8

Hernigou, P., Poignard, A., Beaujean, F., and Rouard, H. (2005). Percutaneous autologous bone-marrow grafting for nonunions: influence of the number and concentration of progenitor cells. J. Bone Jt. Surg. Am. 87, 1430-1437. doi: 10.2106/JBJS.D.02215

Herrmann, M., Hildebrand, M., Menzel, U., Fahy, N., Alini, M., Lang, S., et al. (2019). Phenotypic characterization of bone marrow mononuclear cells and derived stromal cell populations from human iliac crest, vertebral body and femoral head. Int. J. Mol. Sci. 20:3454. doi: 10.3390/ijms20143454

Hofer, H. R., and Tuan, R. S. (2016). Secreted trophic factors of mesenchymal stem cells support neurovascular and musculoskeletal therapies. Stem Cell Res. Ther. 7:131. doi: 10.1186/s13287-016-0394-0

Huang, Z., and Feng, Y. (2017). Exosomes derived from hypoxic colorectal cancer cells promote angiogenesis through Wnt4-Induced $\beta$-catenin signaling in endothelial cells. Oncol. Res. 25, 651-661. doi: $10.3727 / 096504016 X 14752792816791$

Hutton, D. L., Kondragunta, R., Moore, E. M., Hung, B. P., Jia, X., and Grayson, W. L. (2014). Tumor necrosis factor improves vascularization in osteogenic grafts engineered with human adipose-derived stem/stromal cells. PLOS ONE 9:e107199. doi: 10.1371/journal.pone.0107199

Isola, A., and Chen, S. (2016). Exosomes: the messengers of health and disease. Curr. Neuropharmacol. 15, 157-165. doi: $10.2174 / 1570159 \times 14666160825160421$

Jakob, M., Saxer, F., Scotti, C., Schreiner, S., Studer, P., Scherberich, A., et al. (2012). Perspective on the evolution of cell-based bone tissue engineering strategies. Eur. Surg. Res. 49, 1-7. doi: 10.1159/000338362
James, A. W., LaChaud, G., Shen, J., Asatrian, G., Nguyen, V., Zhang, X., et al. (2016). A review of the clinical side effects of bone morphogenetic protein-2. Tissue Eng. Part B Rev. 22, 284-297. doi: 10.1089/ten.teb.2015.0357

Jeppesen, D. K., Fenix, A. M., Franklin, J. L., Higginbotham, J. N., Zhang, Q., Zimmerman, L. J., et al. (2019). Reassessment of exosome composition. Cell 177, 428-445.e18. doi: 10.1016/j.cell.2019.02.029

Jia, Y., Zhu, Y., Qiu, S., Xu, J., and Chai, Y. (2019). Exosomes secreted by endothelial progenitor cells accelerate bone regeneration during distraction osteogenesis by stimulating angiogenesis. Stem Cell Res. Ther. 10:12. doi: 10.1186/s13287-018-1115-7

Johnstone, R. M., Adam, M., Hammond, J. R., Orr, L., and Turbide, C. (1987). Vesicle formation during reticulocyte maturation. Association of plasma membrane activities with released vesicles (exosomes). J. Biol. Chem. 262, 9412-9420.

Jukes, J. M., Both, S. K., Leusink, A., Sterk, L. M. T., Van Blitterswijk, C. A., and De Boer, J. (2008). Endochondral bone tissue engineering using embryonic stem cells. Proc. Natl. Acad. Sci. U.S.A. 105, 6840-6845. doi: $10.1073 /$ pnas. 0711662105

Jung, Y., Bauer, G., and Nolta, J. A. (2012). Concise review: induced pluripotent stem cell-derived mesenchymal stem cells: progress toward safe clinical products. Stem Cells 30, 42-47. doi: 10.1002/stem.727

Jurgens, W. J. F. M., Oedayrajsingh-Varma, M. J., Helder, M. N., ZandiehDoulabi, B., Schouten, T. E., Kuik, D. J., et al. (2008). Effect of tissue-harvesting site on yield of stem cells derived from adipose tissue: implications for cell-based therapies. Cell Tissue Res. 332, 415-426. doi: 10.1007/s00441-007-0555-7

Kaempfen, A., Todorov, A., Güven, S., Largo, R. D., Jaquiéry, C., Scherberich, A., et al. (2015). Engraftment of prevascularized, tissue engineered constructs in a novel rabbit segmental bone defect model. Int. J. Mol. Sci. 16, 12616-12630. doi: 10.3390/ijms160612616

Karlsson, J., Harmankaya, N., Palmquist, A., Atefyekta, S., Omar, O., Tengvall, P., et al. (2016). Stem cell homing using local delivery of plerixafor and stromal derived growth factor-1alpha for improved bone regeneration around Ti-implants. J. Biomed. Mater. Res. Part A 104, 2466-2475. doi: 10.1002/jbm.a.35786

Kassem, M., and Marie, P. J. (2011). Senescence-associated intrinsic mechanisms of osteoblast dysfunctions. Aging Cell 10, 191-197. doi: 10.1111/j.1474-9726.2011.00669.x

Katagiri, W., Kawai, T., Osugi, M., Sugimura-Wakayama, Y., Sakaguchi, K., Kojima, T., et al. (2017). Angiogenesis in newly regenerated bone by secretomes of human mesenchymal stem cells. Maxillofac. Plast. Reconstr. Surg. 39:8. doi: 10.1186/s40902-017-0106-4

Katagiri, W., Osugi, M., Kawai, T., and Hibi, H. (2016). First-in-human study and clinical case reports of the alveolar bone regeneration with the secretome from human mesenchymal stem cells. Head Face Med. 12:5. doi: 10.1186/s13005-016-0101-5

Katagiri, W., Osugi, M., Kawai, T., and Ueda, M. (2013). Novel cell-free regeneration of bone using stem cell-derived growth factors. Int. J. Oral Maxillofac. Implants 28, 1009-1016. doi: 10.11607/jomi.3036

Kawai, T., Katagiri, W., Osugi, M., Sugimura, Y., Hibi, H., and Ueda, M. (2015). Secretomes from bone marrow-derived mesenchymal stromal cells enhance periodontal tissue regeneration. Cytotherapy 17, 369-381. doi: 10.1016/j.jcyt.2014.11.009

Kern, S., Eichler, H., Stoeve, J., Klüter, H., and Bieback, K. (2006). Comparative analysis of mesenchymal stem cells from bone marrow, umbilical cord blood, or adipose tissue. Stem Cells 24, 1294-1301. doi: 10.1634/stemcells.2005-0342

Khojasteh, A., Kheiri, L., Behnia, H., Tehranchi, A., Nazeman, P., Nadjmi, N., et al. (2017). Lateral ramus cortical bone plate in alveolar cleft osteoplasty with concomitant use of buccal fat pad derived cells and autogenous bone: phase I clinical trial. Biomed Res. Int. 2017:6560234. doi: 10.1155/2017/6560234

Lai, R. C., Yeo, R. W. Y., Tan, K. H., and Lim, S. K. (2013). Exosomes for drug delivery-a novel application for the mesenchymal stem cell. Biotechnol. Adv. 31, 543-551. doi: 10.1016/j.biotechadv.2012.08.008

Lamichhane, T. N., Sokic, S., Schardt, J. S., Raiker, R. S., Lin, J. W., and Jay, S. M. (2015). Emerging roles for extracellular vesicles in tissue engineering and regenerative medicine. Tissue Eng. Part B Rev. 21, 45-54. doi: $10.1089 /$ ten.teb.2014.0300

Lapasset, L., Milhavet, O., Prieur, A., Besnard, E., Babled, A., Ät-Hamou, N., et al. (2011). Rejuvenating senescent and centenarian human cells by 
reprogramming through the pluripotent state. Genes Dev. 25, 2248-2253. doi: 10.1101/gad.173922.111

Le Nail, L. R., Stanovici, J., Fournier, J., Splingard, M., Domenech, J., and Rosset, P. (2014). Percutaneous grafting with bone marrow autologous concentrate for open tibia fractures: analysis of forty three cases and literature review. Int. Orthop. 38, 1845-1853. doi: 10.1007/s00264-014-2342-x

Leuning, D. G., Beijer, N. R. M., Du Fossé, N. A., Vermeulen, S., Lievers, E., Van Kooten, C., et al. (2018). The cytokine secretion profile of mesenchymal stromal cells is determined by surface structure of the microenvironment. Sci. Rep. 8:7716. doi: 10.1038/s41598-018-25700-5

Levi, B., Hyun, J. S., Montoro, D. T., Lo, D. D., Chan, C. K. F., Hu, S., et al. (2012). In vivo directed differentiation of pluripotent stem cells for skeletal regeneration. Proc. Natl. Acad. Sci. U.S.A. 109, 20379-20384. doi: 10.1073/pnas.1218052109

Li, B., Menzel, U., Loebel, C., Schmal, H., Alini, M., and Stoddart, M. J. (2016). Monitoring live human mesenchymal stromal cell differentiation and subsequent selection using fluorescent RNA-based probes. Sci. Rep. 6:26014. doi: 10.1038/srep26014

Li, W., Liu, Y., Zhang, P., Tang, Y., Zhou, M., Jiang, W., et al. (2018). Tissue-engineered bone immobilized with human adipose stem cells-derived exosomes promotes bone regeneration. ACS Appl. Mater. Interfaces 10, 5240-5254. doi: 10.1021/acsami.7b17620

Liebergall, M., Schroeder, J., Mosheiff, R., Gazit, Z., Yoram, Z., Rasooly, L., et al. (2013). Stem cell-based therapy for prevention of delayed fracture union: a randomized and prospective preliminary study. Mol. Ther. 21, 1631-1638. doi: $10.1038 / \mathrm{mt} .2013 .109$

Liu, X., Li, Q., Niu, X., Hu, B., Chen, S., Song, W., et al. (2017). Exosomes secreted from human-induced pluripotent stem cell-derived mesenchymal stem cells prevent osteonecrosis of the femoral head by promoting angiogenesis. Int. J. Biol. Sci. 13, 232-244. doi: 10.7150/ijbs.16951

Luzzani, C. D., and Miriuka, S. G. (2017). Pluripotent stem cells as a robust source of mesenchymal stem cells. Stem Cell Rev. Rep. 13, 68-78. doi: 10.1007/s12015-016-9695-Z

Ma, T., Xie, M., Laurent, T., and Ding, S. (2013). Progress in the reprogramming of somatic cells. Circ. Res. 112, 562-574. doi: 10.1161/CIRCRESAHA.111.249235

Manassero, M., Paquet, J., Deschepper, M., Viateau, V., Retortillo, J., Bensidhoum, M., et al. (2016). Comparison of survival and osteogenic ability of human mesenchymal stem cells in orthotopic and ectopic sites in mice. Tissue Eng. Part A 22, 534-544. doi: 10.1089/ten.tea.2015.0346

Marcos-Campos, I., Marolt, D., Petridis, P., Bhumiratana, S., Schmidt, D., and Vunjak-Novakovic, G. (2012). Bone scaffold architecture modulates the development of mineralized bone matrix by human embryonic stem cells. Biomaterials 33, 8329-8342. doi: 10.1016/j.biomaterials.2012.08.013

Marcucio, R. S., Nauth, A., Giannoudis, P. V., Bahney, C., Piuzzi, N. S., Muschler, G., et al. (2015). Stem cell therapies in orthopaedic trauma. J. Orthop. Trauma 29, S24-S27. doi: 10.1097/BOT.0000000000000459

Marie, P. J. (2014). Bone cell senescence: mechanisms and perspectives. J. Bone Miner. Res. 29, 1311-1321. doi: 10.1002/jbmr.2190

Marolt, D., Augst, A., Freed, L. E., Vepari, C., Fajardo, R., Patel, N., et al. (2006). Bone and cartilage tissue constructs grown using human bone marrow stromal cells, silk scaffolds and rotating bioreactors. Biomaterials 27, 6138-6149. doi: 10.1016/j.biomaterials.2006.07.015

Marolt, D., Knezevic, M., and Novakovic, G. V. (2010). Bone tissue engineering with human stem cells. Stem Cell Res. Ther. 1:10. doi: 10.1186/scrt10

Marote, A., Teixeira, F. G., Mendes-Pinheiro, B., and Salgado, A. J. (2016). MSCsderived exosomes: cell-secreted nanovesicles with regenerative potential. Front. Pharmacol. 7:231. doi: 10.3389/fphar.2016.00231

Martin, I., Muraglia, A., Campanile, G., Cancedda, R., and Quarto, R. (1997). Fibroblast growth factor-2 supports ex vivo expansion and maintenance of osteogenic precursors from human bone marrow. Endocrinology 138, 4456-4462. doi: 10.1210/endo.138.10.5425

Mauney, J. R., Kaplan, D. L., and Volloch, V. (2004). Matrix-mediated retention of osteogenic differentiation potential by human adult bone marrow stromal cells during ex vivo expansion. Biomaterials 25, 3233-3243. doi: 10.1016/j.biomaterials.2003.10.005

Mauney, J. R., Kirker-Head, C., Abrahamson, L., Gronowicz, G., Volloch, V., and Kaplan, D. L. (2006). Matrix-mediated retention of in vitro osteogenic differentiation potential and in vivo bone-forming capacity by human adult bone marrow-derived mesenchymal stem cells during ex vivo expansion. J. Biomed. Mater. Res. Part A 79, 464-475. doi: 10.1002/jbm.a.30876

Meinel, L., Fajardo, R., Hofmann, S., Langer, R., Chen, J., Snyder, B., et al. (2005). Silk implants for the healing of critical size bone defects. Bone 37, 688-698. doi: 10.1016/j.bone.2005.06.010

Meinel, L., Hofmann, S., Betz, O., Fajardo, R., Merkle, H. P., Langer, R., et al. (2006). Osteogenesis by human mesenchymal stem cells cultured on silk biomaterials: comparison of adenovirus mediated gene transfer and protein delivery of BMP-2. Biomaterials 27, 4993-5002. doi: 10.1016/j.biomaterials.2006.05.021

Meinel, L., Karageorgiou, V., Fajardo, R., Snyder, B., Shinde-Patil, V., Zichner, L., et al. (2004). Bone tissue engineering using human mesenchymal stem cells: effects of scaffold material and medium flow. Ann. Biomed. Eng. 32, 112-122. doi: 10.1023/B:ABME.0000007796.48329.b4

Méndez-Ferrer, S., Michurina, T. V., Ferraro, F., Mazloom, A. R., MacArthur, B. D., Lira, S. A., et al. (2010). Mesenchymal and haematopoietic stem cells form a unique bone marrow niche. Nature 466, 829-834. doi: 10.1038/nature09262

Mendt, M., Kamerkar, S., Sugimoto, H., McAndrews, K. M., Wu, C. C., Gagea, M., et al. (2018). Generation and testing of clinical-grade exosomes for pancreatic cancer. JCI Insight 3:99263. doi: 10.1172/jci.insight.99263

Mitra, D., Whitehead, J., Yasui, O. W., and Leach, J. K. (2017). Bioreactor culture duration of engineered constructs influences bone formation by mesenchymal stem cells. Biomaterials 146, 29-39. doi: 10.1016/j.biomaterials.2017.08.044

Mizukami, A., Thomé, C. H., Ferreira, G. A., Lanfredi, G. P., Covas, D. T., Pitteri, S. J., et al. (2019). Proteomic identification and time-course monitoring of secreted proteins during expansion of human mesenchymal stem/stromal in stirred-tank bioreactor. Front. Bioeng. Biotechnol. 7:154. doi: 10.3389/fbioe.2019.00154

Murgia, A., Veronesi, E., Candini, O., Caselli, A., D’Souza, N., Rasini, V., et al. (2016). Potency biomarker signature genes from multiparametric osteogenesis assays: will cGMP human bone marrow mesenchymal stromal cells make bone? PLoS ONE 11:e016362. doi: 10.1371/journal.pone.0163629

Muschler, G. F., Boehm, C., and Easley, K. (1997). Aspiration to obtain osteoblast progenitor cells from human bone marrow: the influence of aspiration volume. J. Bone Jt. Surg. Am. 79, 1699-1709. doi: 10.2106/00004623-199711000-00012

Nancarrow-Lei, R., Mafi, P., Mafi, R., and Khan, W. (2017). A systemic review of adult mesenchymal stem cell sources and their multilineage differentiation potential relevant to musculoskeletal tissue repair and regeneration. Curr. Stem Cell Res. Ther. 12, 601-610. doi: 10.2174/1574888X12666170608124303

Ogata, K., Katagiri, W., and Hibi, H. (2017). Secretomes from mesenchymal stem cells participate in the regulation of osteoclastogenesis in vitro. Clin. Oral Investig. 21, 1979-1988. doi: 10.1007/s00784-016-1986-X

Ogata, K., Katagiri, W., Osugi, M., Kawai, T., Sugimura, Y., Hibi, H., et al. (2015). Evaluation of the therapeutic effects of conditioned media from mesenchymal stem cells in a rat bisphosphonate-related osteonecrosis of the jaw-like model. Bone 74, 95-105. doi: 10.1016/j.bone.2015.01.011

Ogata, K., Matsumura, M., Moriyama, M., Katagiri, W., Hibi, H., and Nakamura, S. (2018). Cytokine mixtures mimicking secretomes from mesenchymal stem cells improve medication-related osteonecrosis of the jaw in a rat model. JBMR Plus 2, 69-80. doi: 10.1002/jbm4.10013

Oryan, A., Kamali, A., Moshirib, A., and Eslaminejad, M. B. (2017). Role of mesenchymal stem cells in bone regenerative medicine: what is the evidence? Cells Tissues Organs 204, 59-83. doi: 10.1159/000469704

Osinga, R., Di Maggio, N., Todorov, A., Allafi, N., Barbero, A., Laurent, F., et al. (2016). Generation of a bone organ by human adipose-derived stromal cells through endochondral ossification. Stem Cells Transl. Med. 5, 1090-1097. doi: $10.5966 /$ sctm.2015-0256

Oskowitz, A., McFerrin, H., Gutschow, M., Carter, M. L., and Pochampally, R. (2011). Serum-deprived human multipotent mesenchymal stromal cells (MSCs) are highly angiogenic. Stem Cell Res. 6, 215-225. doi: 10.1016/j.scr.2011.01.004

Osugi, M., Katagiri, W., Yoshimi, R., Inukai, T., Hibi, H., and Ueda, M. (2012). Conditioned media from mesenchymal stem cells enhanced bone regeneration in rat calvarial bone defects. Tissue Eng. Part A 18, 1479-1489. doi: 10.1089/ten.tea.2011.0325

Park, D., Spencer, J. A., Koh, B. I., Kobayashi, T., Fujisaki, J., Clemens, T. L., et al. (2012). Endogenous bone marrow MSCs are dynamic, fate-restricted 
participants in bone maintenance and regeneration. Cell Stem Cell 10, 259-272. doi: 10.1016/j.stem.2012.02.003

Patterson, T. E., Boehm, C., Nakamoto, C., Rozic, R., Walker, E., Piuzzi, N. S., et al. (2017). The efficiency of bone marrow aspiration for the harvest of connective tissue progenitors from the human iliac crest. J. Bone Jt. Surg. Am. 99, 1673-1682. doi: 10.2106/JBJS.17.00094

Petite, H., Viateau, V., Bensaïd, W., Meunier, A., De Pollak, C., Bourguignon, M., et al. (2000). Tissue-engineered bone regeneration. Nat. Biotechnol. 18, 959-963. doi: 10.1038/79449

Phetfong, J., Sanvoranart, T., Nartprayut, K., Nimsanor, N., Seenprachawong, K., Prachayasittikul, V., et al. (2016). Osteoporosis: the current status of mesenchymal stem cell-based therapy. Cell. Mol. Biol. Lett. 21:12. doi: 10.1186/s11658-016-0013-1

Phillips, M. D., Kuznetsov, S. A., Cherman, N., Park, K., Chen, K. G., McClendon, B. N., et al. (2014). Directed differentiation of human induced pluripotent stem cells toward bone and cartilage: in vitro versus in vivo assays. Stem Cells Transl. Med. 3, 867-878. doi: 10.5966/sctm.2013-0154

Pierini, M., Di Bella, C., Dozza, B., Frisoni, T., Martella, E., Bellotti, C., et al. (2013). The posterior iliac crest outperforms the anterior iliac crest when obtaining mesenchymal stem cells from bone marrow. J. Bone Jt. Surg. Am. 95, 1101-1107. doi: 10.2106/JBJS.L.00429

Pittenger, M. F., Mackay, A. M., Beck, S. C., Jaiswal, R. K., Douglas, R., Mosca, J. D., et al. (1999). Multilineage potential of adult human mesenchymal stem cells. Science 284, 143-147. doi: 10.1126/science.284.5411.143

Ponte, A. L., Marais, E., Gallay, N., Langonné, A., Delorme, B., Hérault, O., et al. (2007). The in vitro migration capacity of human bone marrow mesenchymal stem cells: comparison of chemokine and growth factor chemotactic activities. Stem Cells 25, 1737-1745. doi: 10.1634/stemcells.2007-0054

Qi, X., Zhang, J., Yuan, H., Xu, Z., Li, Q., Niu, X., et al. (2016). Exosomes secreted by human-induced pluripotent stem cell-derived mesenchymal stem cells repair critical-sized bone defects through enhanced angiogenesis and osteogenesis in osteoporotic rats. Int. J. Biol. Sci. 12, 836-849. doi: 10.7150/ijbs.14809

Qin, Y., Wang, L., Gao, Z., Chen, G., and Zhang, C. (2016). Bone marrow stromal/stem cell-derived extracellular vesicles regulate osteoblast activity and differentiation in vitro and promote bone regeneration in vivo. Sci. Rep. 6:21961. doi: 10.1038/srep21961

Quarto, R., Mastrogiacomo, M., Cancedda, R., Kutepov, S. M., Mukhachev, V., Lavroukov, A., et al. (2001). Repair of large bone defects with the use of autologous bone marrow stromal cells. N. Engl. J. Med. 344, 385-386. doi: 10.1056/NEJM200102013440516

Quesenberry, P. J., Aliotta, J., Deregibus, M. C., and Camussi, G. (2015). Role of extracellular RNA-carrying vesicles in cell differentiation and reprogramming. Stem Cell Res. Ther. 6:153. doi: 10.1186/s13287-015-0150-x

Rakian, R., Block, T. J., Johnson, S. M., Marinkovic, M., Wu, J., Dai, Q., et al. (2015). Native extracellular matrix preserves mesenchymal stem cell "stemness" and differentiation potential under serum-free culture conditions. Stem Cell Res. Ther. 6:235. doi: 10.1186/s13287-015-0235-6

Raposo, G., Nijman, H. W., Stoorvogel, W., Leijendekker, R., Harding, C. V., Melief, C. J. M., et al. (1996). B lymphocytes secrete antigen-presenting vesicles. J. Exp. Med. 183, 1161-1172. doi: 10.1084/jem.183.3.1161

Ratajczak, J., Miekus, K., Kucia, M., Zhang, J., Reca, R., Dvorak, P., et al. (2006). Embryonic stem cell-derived microvesicles reprogram hematopoietic progenitors: evidence for horizontal transfer of mRNA and protein delivery. Leukemia 20, 847-856. doi: 10.1038/sj.leu.2404132

Redondo, L. M., García, V., Peral, B., Verrier, A., Becerra, J., Sánchez, A., et al. (2018). Repair of maxillary cystic bone defects with mesenchymal stem cells seeded on a cross-linked serum scaffold. J. Cranio Maxillofac. Surg. 46, 222-229. doi: 10.1016/j.jcms.2017.11.004

Reinisch, A., Etchart, N., Thomas, D., Hofmann, N. A., Fruehwirth, M., Sinha, S., et al. (2015). Epigenetic and in vivo comparison of diverse MSC sources reveals an endochondral signature for human hematopoietic niche formation. Blood 125, 249-260. doi: 10.1182/blood-2014-04-572255

Reumann, M. K., Linnemann, C., Aspera-Werz, R. H., Arnold, S., Held, M., Seeliger, C., et al. (2018). Donor site location is critical for proliferation, stem cell capacity, and osteogenic differentiation of adipose mesenchymal stem/stromal cells: Implications for bone tissue engineering. Int. J. Mol. Sci. 19:E1868. doi: 10.3390/ijms19071868
Rindone, A. N., Kachniarz, B., Achebe, C. C., Riddle, R. C., O’Sullivan, A. N., Dorafshar, A. H., et al. (2019). Heparin-conjugated decellularized bone particles promote enhanced osteogenic signaling of PDGF-BB to adiposederived stem cells in tissue engineered bone grafts. Adv. Healthc. Mater. 8:e1801565. doi: 10.1002/adhm.201801565

Robey, P. G. (2011). Cell sources for bone regeneration: the good, the bad, and the ugly (but promising). Tissue Eng. Part B Rev. 17, 423-430. doi: 10.1089/ten.teb.2011.0199

Robey, P. G., Kuznetsov, S. A., Ren, J., Klein, H. G., Sabatino, M., and Stroncek, D. F. (2015). Generation of clinical grade human bone marrow stromal cells for use in bone regeneration. Bone 70, 87-92. doi: 10.1016/j.bone.2014.07.020

Rohde, E., Pachler, K., and Gimona, M. (2019). Manufacturing and characterization of extracellular vesicles from umbilical cord-derived mesenchymal stromal cells for clinical testing. Cytotherapy 21, 581-592. doi: 10.1016/j.jcyt.2018.12.006

Sacchetti, B., Funari, A., Michienzi, S., Di Cesare, S., Piersanti, S., Saggio, I., et al. (2007). Self-renewing osteoprogenitors in bone marrow sinusoids can organize a hematopoietic microenvironment. Cell 131, 324-336. doi: 10.1016/j.cell.2007.08.025

Schallmoser, K., Rohde, E., Bartmann, C., Obenauf, A. C., Reinisch, A., and Strunk, D. (2009). Platelet-derived growth factors for GMP-compliant propagation of mesenchymal stromal cells. Biomed. Mater. Eng. 19, 271-276. doi: 10.3233/BME-2009-0591

Schuh, C. M. A. P., Cuenca, J., Alcayaga-Miranda, F., and Khoury, M. (2019). Exosomes on the border of species and kingdom intercommunication. Transl. Res. 210, 80-98. doi: 10.1016/j.trsl.2019.03.008

Sensebé, L., Gadelorge, M., and Fleury-Cappellesso, S. (2013). Production of mesenchymal stromal/stem cells according to good manufacturing practices: a review. Stem Cell Res. Ther. 4:66. doi: 10.1186/scrt217

Serra, S. C., Costa, J. C., Assunção-Silva, R. C., Teixeira, F. G., Silva, N. A., Anjo, S. I., et al. (2018). Influence of passage number on the impact of the secretome of adipose tissue stem cells on neural survival, neurodifferentiation and axonal growth. Biochimie 155, 119-128. doi: 10.1016/j.biochi.2018.09.012

Sheyn, D., Shapiro, G., Tawackoli, W., Jun, D. S., Koh, Y., Kang, K. B., et al. (2016). PTH induces systemically administered mesenchymal stem cells to migrate to and regenerate spine injuries. Mol. Ther. 24, 318-330. doi: 10.1038/mt.2015.211

Sikavitsas, V. I., Bancroft, G. N., Holtorf, H. L., Jansen, J. A., and Mikos, A. G. (2003). Mineralized matrix deposition by marrow stromal osteoblasts in 3D perfusion culture increases with increasing fluid shear forces. Proc. Natl. Acad. Sci. U.S.A. 100, 14683-14688. doi: 10.1073/pnas.2434367100

Sladkova, M., Alawadhi, R., Alhaddad, R. J., Esmael, A., Alansari, S., Saad, M., et al. (2018). Segmental additive tissue engineering. Sci. Rep. 8:10895. doi: 10.1038/s41598-018-29270-4

Sørensen, J. R., Koroma, K. E., Ding, M., Wendt, D., Jespersen, S., Juhl, M. V., et al. (2012). Effects of a perfusion bioreactor activated novel bone substitute in spine fusion in sheep. Eur. Spine J. 21, 1740-1747. doi: 10.1007/s00586-012-2421-x

Spitzhorn, L. S., Megges, M., Wruck, W., Rahman, M. S., Otte, J., Degistirici, Ö., et al. (2019). Human iPSC-derived MSCs (iMSCs) from aged individuals acquire a rejuvenation signature. Stem Cell Res. Ther. 10:100. doi: 10.1186/s13287-019-1209-x

Stegemann, J. P., Verrier, S., Gebhard, F., Laschke, M. W., Martin, I., Simpson, H., et al. (2014). Cell therapy for bone repair: narrowing the gap between vision and practice. Eur. Cells Mater. 27, 1-4. doi: 10.22203/eCM.v027sa01

Stolzing, A., Jones, E., McGonagle, D., and Scutt, A. (2008). Age-related changes in human bone marrow-derived mesenchymal stem cells: consequences for cell therapies. Mech. Ageing Dev. 129, 163-173. doi: 10.1016/j.mad.2007. 12.002

Sudo, K., Kanno, M., Miharada, K., Ogawa, S., Hiroyama, T., Saijo, K., et al. (2007). Mesenchymal progenitors able to differentiate into osteogenic, chondrogenic, and/or adipogenic cells in vitro are present in most primary fibroblast-like cell populations. Stem Cells 25, 1610-1617. doi: 10.1634/stemcells.2006-0504

Sutaria, D. S., Badawi, M., Phelps, M. A., and Schmittgen, T. D. (2017). Achieving the promise of therapeutic extracellular vesicles: the devil is in details of therapeutic loading. Pharm. Res. 34, 1053-1066. doi: 10.1007/s11095-017-2123-5

Takahashi, K., Tanabe, K., Ohnuki, M., Narita, M., Ichisaka, T., Tomoda, K., et al. (2007). Induction of pluripotent stem cells from adult human fibroblasts by defined factors. Cell 131, 861-872. doi: 10.1016/j.cell.2007.11.019 
Teixeira, F. G., Panchalingam, K. M., Assunção-Silva, R., Serra, S. C., MendesPinheiro, B., Patrício, P., et al. (2016). Modulation of the mesenchymal stem cell secretome using computer-controlled bioreactors: impact on neuronal cell proliferation, survival and differentiation. Sci. Rep. 6:27791. doi: $10.1038 /$ srep27791

Tencerova, M., Frost, M., Figeac, F., Nielsen, T. K., Ali, D., Lauterlein, J. J. L., et al. (2019). Obesity-associated hypermetabolism and accelerated senescence of bone marrow stromal stem cells suggest a potential mechanism for bone fragility. Cell Rep. 27, 2050-2062.e6. doi: 10.1016/j.celrep.2019.04.066

Timmers, L., Lim, S. K., Arslan, F., Armstrong, J. S., Hoefer, I. E., Doevendans, P. A., et al. (2008). Reduction of myocardial infarct size by human mesenchymal stem cell conditioned medium. Stem Cell Res. 1, 129-137. doi: 10.1016/j.scr.2008.02.002

Timmins, N. E., Scherberich, A., Früh, J. A., Heberer, M., Martin, I., and Jakob, M. (2007). Three-dimensional cell culture and tissue engineering in a T-CUP (tissue culture under perfusion). Tissue Eng. 13, 2021-2028. doi: $10.1089 /$ ten.2006.0158

Tonnarelli, B., Centola, M., Barbero, A., Zeller, R., and Martin, I. (2014). Reengineering development to instruct tissue regeneration. Curr. Top. Dev. Biol. 108, 319-338. doi: 10.1016/B978-0-12-391498-9.00005-X

Topoluk, N., Hawkins, R., Tokish, J., and Mercuri, J. (2017). Amniotic mesenchymal stromal cells exhibit preferential osteogenic and chondrogenic differentiation and enhanced matrix production compared with adipose mesenchymal stromal cells. Am. J. Sports Med. 45, 2637-2646. doi: $10.1177 / 0363546517706138$

Tricarico, C., Clancy, J., and D'Souza-Schorey, C. (2017). Biology and biogenesis of shed microvesicles. Small GTPases 8, 220-232. doi: 10.1080/21541248.2016.1215283

Turchinovich, A., Drapkina, O., and Tonevitsky, A. (2019). Transcriptome of extracellular vesicles: state-of-the-art. Front. Immunol. 10:202. doi: 10.3389/fimmu.2019.00202

Tzioupis, C., and Giannoudis, P. V. (2007). Prevalence of long-bone non-unions. Injury 38:S3. doi: 10.1016/j.injury.2007.02.005

van Balkom, B. W. M., Gremmels, H., Giebel, B., and Lim, S. K. (2019). Proteomic signature of mesenchymal stromal cell-derived small extracellular vesicles. Proteomics 19:e1800163. doi: 10.1002/pmic.201800163

Van Niel, G., D'Angelo, G., and Raposo, G. (2018). Shedding light on the cell biology of extracellular vesicles. Nat. Rev. Mol. Cell Biol. 19, 213-228. doi: $10.1038 / \mathrm{nrm} .2017 .125$

Vetsch, J. R., Müller, R., and Hofmann, S. (2016). The influence of curvature on three-dimensional mineralized matrix formation under static and perfused conditions: an in vitro bioreactor model. J. R. Soc. Interface 13:2016042. doi: 10.1098/rsif.2016.0425

Wang, B., Lee, W. Y. W., Huang, B., Zhang, J. F., Wu, T. Y., Jiang, X., et al. (2016). Secretome of human fetal mesenchymal stem cell ameliorates replicative senescen. Stem Cells Dev. 25, 1755-1766. doi: 10.1089/scd.2016.0079

Webber, J., and Clayton, A. (2013). How pure are your vesicles? J. Extracell. Vesicles 2. doi: $10.3402 /$ jev.v2i0.19861

Weilner, S., Schraml, E., Wieser, M., Messner, P., Schneider, K., Wassermann, K., et al. (2016). Secreted microvesicular miR-31 inhibits osteogenic differentiation of mesenchymal stem cells. Aging Cell 15, 744-754. doi: 10.1111/acel.12484

Whitford, W., and Guterstam, P. (2019). Exosome manufacturing status. Future Med. Chem. 11, 1225-1236. doi: 10.4155/fmc-2018-0417

Willms, E., Johansson, H. J., Mäger, I., Lee, Y., Blomberg, K. E. M., Sadik, M., et al. (2016). Cells release subpopulations of exosomes with distinct molecular and biological properties. Sci. Rep. 6:22519. doi: 10.1038/srep22519

Witwer, K. W., Van Balkom, B. W. M., Bruno, S., Choo, A., Dominici, M., Gimona, M., et al. (2019). Defining mesenchymal stromal cell (MSC)-derived small extracellular vesicles for therapeutic applications. J. Extracell. Vesicles 8:1609206. doi: 10.1080/20013078.2019.1609206

Woloszyk, A., Dircksen, S. H., Bostanci, N., Muöller, R., Hofmann, S., and Mitsiadis, T. A. (2014). Influence of the mechanical environment on the engineering of mineralised tissues using human dental pulp stem cells and silk fibroin scaffolds. PLoS ONE 9:e111010. doi: 10.1371/journal.pone.0111010

Wu, Q., Yang, B., Hu, K., Cao, C., Man, Y., and Wang, P. (2017). Deriving osteogenic cells from induced pluripotent stem cells for bone tissue engineering. Tissue Eng. Part B Rev. 23, 1-8. doi: 10.1089/ten.teb.2015.0559
Xie, H., Wang, Z., Zhang, L., Lei, Q., Zhao, A., Wang, H., et al. (2017). Extracellular vesicle-functionalized decalcified bone matrix scaffolds with enhanced pro-angiogenic and pro-bone regeneration activities. Sci. Rep. 7:45622. doi: 10.1038/srep45622

Xu, J., Wang, B., Sun, Y., Wu, T., Liu, Y., Zhang, J., et al. (2016). Human fetal mesenchymal stem cell secretome enhances bone consolidation in distraction osteogenesis. Stem Cell Res. Ther. 7:134. doi: 10.1186/s13287-0160392-2

Yao, W., and Lane, N. E. (2015). Targeted delivery of mesenchymal stem cells to the bone. Bone 70, 62-65. doi: 10.1016/j.bone.2014.07.026

Yao, W., Lay, Y. A. E., Kot, A., Liu, R., Zhang, H., Chen, H., et al. (2016). Improved mobilization of exogenous mesenchymal stem cells to bone for fracture healing and sex difference. Stem Cells 34, 2587-2600. doi: 10.1002/ste m. 2433

Yeo, R. W. Y., Lai, R. C., Zhang, B., Tan, S. S., Yin, Y., Teh, B. J., et al. (2013). Mesenchymal stem cell: an efficient mass producer of exosomes for drug delivery. Adv. Drug Deliv. Rev. 65, 336-341. doi: 10.1016/j.addr.2012. 07.001

Zhang, B., Yin, Y., Lai, R. C., Tan, S. S., Choo, A. B. H., and Lim, S. K. (2014). Mesenchymal stem cells secrete immunologically active exosomes. Stem Cells Dev. 23, 1233-1244. doi: 10.1089/scd.2013.0479

Zhang, J., Liu, X., Li, H., Chen, C., Hu, B., Niu, X., et al. (2016a). Exosomes/tricalcium phosphate combination scaffolds can enhance bone regeneration by activating the PI3K/Akt signaling pathway. Stem Cell Res. Ther. 7:136. doi: 10.1186/s13287-016-0391-3

Zhang, S., Chu, W. C., Lai, R. C., Lim, S. K., Hui, J. H. P., and Toh, W. S. (2016b). Exosomes derived from human embryonic mesenchymal stem cells promote osteochondral regeneration. Osteoarthr. Cartil. 24, 2135-2140. doi: 10.1016/j.joca.2016.06.022

Zhang, X., Hirai, M., Cantero, S., Ciubotariu, R., Dobrila, L., Hirsh, A., et al. (2011). Isolation and characterization of mesenchymal stem cells from human umbilical cord blood: reevaluation of critical factors for successful isolation and high ability to proliferate and differentiate to chondrocytes as compared to mesenchymal stem cells from bone marrow and adipose tissue. J. Cell. Biochem. 112, 1206-1218. doi: 10.1002/jcb.23042

Zhang, Y., Hao, Z., Wang, P., Xia, Y., Wu, J., Xia, D., et al. (2019). Exosomes from human umbilical cord mesenchymal stem cells enhance fracture healing through HIF-1 $\alpha$-mediated promotion of angiogenesis in a rat model of stabilized fracture. Cell Prolif. 52:e12570. doi: 10.1111/cpr.12570

Zhao, F., van Rietbergen, B., Ito, K., and Hofmann, S. (2018). Flow rates in perfusion bioreactors to maximise mineralisation in bone tissue engineering in vitro. J. Biomech. 79, 232-237. doi: 10.1016/j.jbiomech.2018.08.004

Zhou, B. O., Yue, R., Murphy, M. M., Peyer, J. G., and Morrison, S. J. (2014). Leptin-receptor-expressing mesenchymal stromal cells represent the main source of bone formed by adult bone marrow. Cell Stem Cell 15, 154-168. doi: 10.1016/j.stem.2014.06.008

Zhu, S., Li, W., Zhou, H., Wei, W., Ambasudhan, R., Lin, T., et al. (2010). Reprogramming of human primary somatic cells by OCT4 and chemical compounds. Cell Stem Cell 7, 651-655. doi: 10.1016/j.stem.2010.11.015

Zhu, Y., Jia, Y., Wang, Y., Xu, J., and Chai, Y. (2019). Impaired bone regenerative effect of exosomes derived from bone marrow mesenchymal stem cells in type 1 diabetes. Stem Cells Transl. Med. 8, 593-605. doi: 10.1002/sctm.18-0199

Zuk, P. A., Zhu, M., Mizuno, H., Huang, J., Futrell, J. W., Katz, A. J., et al. (2001). Multilineage cells from human adipose tissue: implications for cell-based therapies. Tissue Eng. 7, 211-228. doi: 10.1089/107632701300062859

Conflict of Interest: The authors declare that the research was conducted in the absence of any commercial or financial relationships that could be construed as a potential conflict of interest.

Copyright (C) 2019 Marolt Presen, Traweger, Gimona and Redl. This is an open-access article distributed under the terms of the Creative Commons Attribution License (CC $B Y)$. The use, distribution or reproduction in other forums is permitted, provided the original author(s) and the copyright owner(s) are credited and that the original publication in this journal is cited, in accordance with accepted academic practice. No use, distribution or reproduction is permitted which does not comply with these terms. 